\title{
Does the Shanghai Cooperation Represent an Example of a Military Alliance?
}

\author{
By T.Tugsbilguun (Mongolia)
}

Abstract

Te Shanghai Cooperation Organization (SCO) is a multilateral security organization established in 2001 with the participation of China, Russia and four Central Asian states including Kazakhstan, Kyrgyzstan, Tajikistan and Uzbekistan. It is often perceived by some analysts in the West as an anti-US or anti-Western alliance. This article attempts to answer to the question: Does the SCO represent an example of a military alliance?

The article will answer to the above question by examining the empirical factors of the SCO with reference to alliance theory in International Relations. Although it concludes that the SCO cannot be considered as a military "alliance" from the theoretical and empirical standpoints, it nevertheless contains the potential to evolve into a more mature security organization which does not necessarily have to be in conformity with traditional alliance theory.

\section{Introduction}

Founded in 2001 with China, the Russian Federation, Kazakhstan, Kyrgyzstan, Tajikistan and Uzbekistan as members, the Shanghai Cooperation Organization (SCO) is an emerging multilateral organization in Central Asia and has been characterized as a security organization, a regional

${ }^{*}$ Tugsbilguun Tumurkhuleg is an officer at the Ministry of Foreign Affairs and Trade of Mongolia. In December 2008 he graduated from the Australian National University in Canberra, Australia with the Master of Arts (International Relations) degree with honors. In the last semester of his program he wrote thesis entitled "Does the Shanghai Cooperation Organization represent an example of a military alliance?" which received a high distinction mark. The main ideas of his thesis are presented in this article. 
forum, and an anti-terrorism coalition. Another widespread perception of the SCO is as a Russian and Chinese-led alliance created to counterbalance the US supremacy both at the regional and global levels. Indeed, a number of analysts, especially in the US have compared the SCO with the Warsaw Pact, and speculated over whether this organization might develop into a counterweight to the North Atlantic Treaty Organization (NATO) and whether the world is witnessing the start of a new Eastern bloc. 'In particular, an expert on East Asia, Frederick W. Stakelbeck, Jr. explicitly states that "the SCO is a menacing confederacy of powerful nations arising out shadows of the Cold War that could cause tremendous global instability and even lead to war".2 Notwithstanding the fact that India and Iran are only observers, with huge differences in terms of foreign policy, he goes on to highlight that this organization has the potential of turning into the most powerful alliance on earth, given the combination of Russia's energy, military and technology expertise; China and India's economic and human capital, and Iran's enormous energy resources as well as growing military capabilities. ${ }^{3}$ According to Stakelbeck, "this unique combination makes the SCO a formidable adversary for the US".4 In a similar vein, Peter Brookes, a senior fellow at the Heritage Foundation, asserts that "Russia may be

' See for example Frederick W. Stakelbeck, Jr., "Is the Shanghai Cooperation Organization a Military Confederacy?", Globalpolitician.com,<http://www. globalpolitician.com/21244-russia-china> (accessed on October 17, 2008); Peter Brookes, "Club For Dictators: An ugly agenda for Asia", The Heritage Foundation, June 12, 2006, Heritage.org, <http://www.heritage.org/Press/Commentary/ed061206b.ffm> (accessed on April 09, 2007); Jehangir S. Pocha, "Summit forges military ties in Central Asia. Six nations also consider forming an 'energy club"', The Boston Globe, June 18, 2006; Ariel Cohen and John J. Tkacik, Jr., "Sino-Russian Military Maneuvers: A Threat to U.S. Interests in Eurasia", The Heritage Foundation, Backgrounder 1883, September 30, 2005, Heritage. org, <http://www.heritage.org/research/russiaandeurasia/bg1883.ffm>

(accessed on August 21, 2008); Jonathan Watts, "China Hosts Summit to Rival US", The Guardian, 15 June 2006; Benjamin Goldsmith, "Here There Be Dragons: The Shanghai Cooperation Organization", The Center for Defense Information, September 2005, Ciaonet. org, <http://www.ciaonet.org/wps/cdi014/> (accessed on March 20, 2007)

Stakelbeck, Jr., "Is the Shanghai Cooperation Organization a Military Confederacy?"

${ }^{3}$ bid

${ }^{4} \mathrm{lbid}$ looking to create 'a new and improved' Asian Warsaw Pact, wielding large armies, big economies, nukes and lots of oil/gas".

Moreover, some SCO actions such as its 2005 Astana Declaration, in which the grouping demanded the US to provide a timetable for withdrawal of its bases from Central Asia, ${ }^{6}$ as well as its joint military exercises, particularly those conducted in 2005 and 2007 involving military forces primarily from Russia and China, raised concerns that the SCO intends to establish a military bloc to compete with NATO and diminish the US presence in Central Asia. US analysts Ariel Cohen and John J. Tkacik, Jr. view these developments as evidences of the fact that "the anti-American axis has already begun to work"?

In contrast, the political leaders and most analysts in the SCO member states, especially those in its two most influential members, Russia and China, have repeatedly emphasized that the SCO is not a military alliance, since it is not directed against a third party and is only interested in combating threats posed by terrorism, separatism and extremism. ${ }^{8}$ As Russian scholar Alexander Lukin asserts "attempts to turn this organization into an anti-Western or anti-US bloc are doomed to fail because this would contradict the fundamental interests of its members who are interested in cooperating with the West in many areas". ${ }^{9}$ Moreover, in their view, the SCO represents a new kind of phenomenon in international relations that transcends obsolete "bloc-style thinking" of the Cold War period. For

5Brookes, "Club For Dictators: An ugly agenda for Asia"

${ }^{6}$ For details see: Declaration of Heads of Member States of the Shanghai Cooperation Organization, Astana, 5 July 2005, Sectsco.org, <http://www.sectsco.org/html/00500. html> (accessed on March 21, 2007)

"Cohen and Tkacik, Jr., "Sino-Russian in Eurasia", p.3

${ }^{8}$ See for example the Shanghai Convention on Combating Terrorism, Separatism and Extremism, Shanghai, June 15, 2001, Sectsco.org, <http://www.sectsco.org/html/0093> (accessed on March 25, 2007); Vladimir Putin, "SCO: a new model of successful international cooperation", Moscow, June 14, 2006, Kremlin.ru, <http://www.kremlin.ru/eng/sdocs/ speeches.shtml> (accessed on April 04, 2007); Yang Jiechi, "Eternal driving force of Shanghai Spirit", Renmin Ribao, June 16, 2008 [a Mongolian translation of this article was obtained by author from the Ministry of Foreign Affairs of Mongolia]

"Alexander Lukin, "Rossiya i ShOS" [Russia and SCO], Analyticheskiye Zapiski, no.6 (26) (Jul.2007), p.4 
instance, Director of the SCO Studies Center in Shanghai, Pan Guang, emphasizes that "the SCO has helped to shape a new model of state-to state relationships 10 characterized by partnership but not alliance, as originally spearheaded by China and Russia.".1 He further contends that "the relationship between China, Russia and the Central Asian states under the SCO umbrella - constitutes a close partnership with constructive intentions while stopping short of military alliance".12

However, it should also be noted that not all international relations and military experts in Russia and China hold such benign views with respect to the SCO's standing vis-à-vis the West. In particular, retired Colonel-General Leonid Ivashov, former head of the International Military Cooperation Directorate at the Russian Ministry of Defense who currently serves as the President of the Academy of Geopolitical Problems in Moscow, bluntly states that:

Under conditions of NATO expansion, there is a real threat to national security of Russia. Hence, I am convinced that only SCO could become a real counterweight to expansion on the part of the North Atlantic Alliance. In the future, what the SCO needs to do is to admit Iran, India and Pakistan as its members. ${ }^{13}$

In reference to the purpose of the Sino-Russian military exercise "Peace Mission 2005" conducted within the framework of the SCO, Professor of International Relations at the People's University of China Jin Canrong is similarly frank asserting that "the main target is the United States. Both sides want to improve their bargaining position in terms of security, politics and economics",

As seen from the above-stated views, the Shanghai Cooperation Organization has become an object of significant disagreements among

\section{${ }^{10}$ Italic is in text}

"Pan Guang, "A Chinese Perspective on the Shanghai Cooperation Organization", The Shanghai Cooperation Organization, SIPRI Policy Paper No.17, (Stockholm: Stockholm International Peace Research Institute, May 2007), p.47

${ }^{12}$ lbid.

${ }^{13}$ "ShOS suzhdeno stat' voyennym al'yansom" [SCO is destined to become a military alliancel, Ramblerru, May 15, 2008, <http///www ramblerru/news/politics/0/562184254. html> (accessed on August 25, 2008)

${ }^{14} \mathrm{Jin}$ Canrong quoted in Cohen and Tkacik, Jr., "Sino-Russian Military Maneuvers: A Threat to U.S. Interests in Eurasia", p. foreign policy scholars and practitioners with regard to its goals and activities, particularly military component of its cooperation. Therefore, this article attempts to answer to the question: does the SCO represent an example of a military alliance?

In order to answer the above question this article will proceed as follows. The first part of the article will briefly review the alliance theory literature with the aim to specify what is meant by "alliance" in IR Theory. Apart from explaining the reason for the absence of a single acceptable definition of the term "alliance", it will provide succinct distinction between the close, yet distinctive terms of "alliance" and "alignment". Moreover, it will demonstrate that in the post-Cold War and post-9/11 world, the concept of "alliance" has significantly changed from its classical Cold War era meaning.

The second part will briefly describe the history of the development of the $\mathrm{SCO}$, in order to help better understand the nature and essence of this organization

The third part will discuss respective interests of the two predominant members of SCO, China and Russia, as well as those of its other four Central Asian members, and in addition, four observer states, including India, Iran, Mongolia and Pakistan. In discussing the interests of China and Russia, it will touch upon the Russo-Chinese strategic partnership upon which the SCO is based. Moreover, this part will demonstrate that there exists a host of empirical factors making it unfeasible to turn this organization into a full-fledged military alliance such as the hidden divergence of interests between Russia and China, mutual suspicion of each other's motives and intentions, absence of a natural empathy and harmony between Central Asian states-members of the $\mathrm{SCO}$ and different motivations of its observers for affiliating with the SCO. Thus, a discussion of these interests would contribute to understanding why the SCO is unlikely to develop into a typical military alliance.

On the conceptual base discussed in first part as well as empirical factors reviewed in the second and third parts, the fourth part will analyze the SCO in detail with regard to answering the question of whether it can be considered as an alliance. In doing so, it will demonstrate how the SCO meets and defies conventional alliance theory. Besides theory, equal attention will be given to examination of empirical factors as a whole. Having examined the conceptual and empirical factors, it will be emphasized that conventional alliance theory has a limited application in

Number 15-16, 2008- 2009 
explaining the phenomenon of the $\mathrm{SCO}$, while the closest resemblance it has, is with the "pattern of alignment".

Finally, the article will be concluded by arguing that the SCO represents a new model of alignment system characterized by a more informal and flexible nature, which in turn, represents the true dynamics of the changing security environment of the 21 st century. Therefore, despite the fact that at present it is still premature to conclude that the SCO is a military alliance from traditional theoretical and empirical perspectives, it nevertheless contains the potential to evolve into a more mature security organization which does not necessarily have to conform to traditional alliance theories.

I. What is an alliance? Alliance vs. Alignment

It could be well-observed that in IR literature the question of what defines an "alliance" is still essentially contested with many authors putting forward different definitions but coming up short of agreeing on a single acceptable definition. As Paul Schroeder rightly points out "the term 'alliance' has often been used loosely to mean simply 'friendship' or 'working partnership'.'15 George Liska expresses a similar view to Schroeder when he states that "it has always been difficult to say much that is peculiar to alliances on the plane of general analysis".16

The reason for such a state of affairs seems to lie in terminology, especially in the fact that such closely related, yet distinctive terms as "alliance" and "alignment" have been often used in academic literature interchangeably. This fact is emphasized in the works of a number of well-known authorities in the study of alliances, for example, Roger Dingman and Glenn Snyder among others. ${ }^{17}$ In particular, Dingman observes that historians have rarely attempted to define alliance and brings

${ }^{15}$ Paul W. Schroeder, "Alliances 1815-1945: Weapons of Power and Tools of Managemene, in Klaus Knorr, ed., Historical Dimensions of National Security, (Lawrence: University Press of Kansas, 1976), p.227

${ }^{16}$ George Liska quoted in George Modelski, "Review: The Study of Alliances", The Journal of Conflict Resolution, Vol.7, No.4 (December 1963), p.769

${ }^{17}$ See Roger V. Dingman, "Theories of, and Approaches to, Alliance Politics", in Paul Gordon Lauren, ed., Diplomacy: New Approaches in History, Theory and Policy, (London: Collier Macmillan Publishers, 1979), p.246 and Glenn H. Snyder, Alliance Politics, (Ithaca and London: Cornell University Press, 1997), p.6 up as an example William L. Langer's classic study on alliance diplomacy, European Alliances and Alignments from the title of which it is clear that "writers of international relations textbooks seem to have followed a similar course".19 In this context, he notes that since such terms as coalitions, ententes, or alignments had not been distinguished from alliances, they have been frequently misused as synonyms. ${ }^{20}$ Thus, he proposes his own definition of alliance as "a specific form of international relationship" which refers to:

a written, formal agreement among two or more states which is designed to serve, for a specified term, the interests of those states or of their statesmen and bureaucrats, in regard to national security. ${ }^{21}$

Snyder agrees with Dingman's observation that the terms "alliance" and "alignments" have been employed in IR literature interchangeably and on his part, makes specific distinctions between the two terms. According to Snyder, alignment is a broader and more fundamental term, which is defined as "expectations of states about whether they will be supported or opposed by other states in future interactions".22 As he further elaborates, alignment includes alignment "against" as well as "with", identifying potential opponents as well as friends. In general, such expectations arise from the perceived interests, capabilities, and observed behavior of other states, including their alliance pledges. In this connection, Snyder underlines that "they may only be vague estimates rather than certainties or even probabilities". 23

As for the term "alliance", Snyder's definition is as follows: "Alliances are formal associations of states for the use (or nonuse) of military force, in specified circumstances, against states outside their own membership ${ }^{\prime 24}$. He further states that:

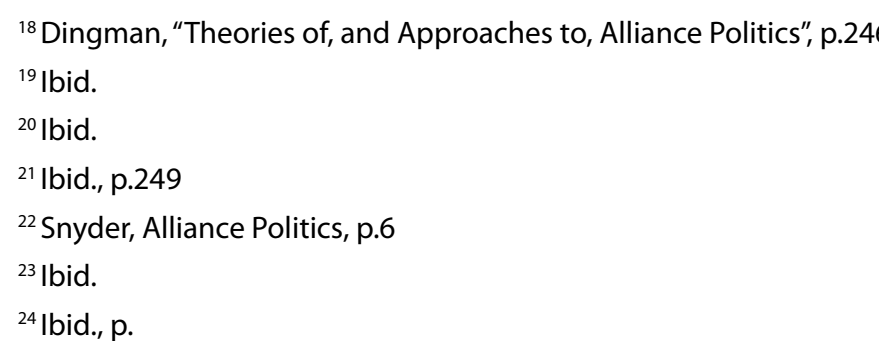


...alliance, properly speaking, can be the result only of a formal agreement of some sort that makes explicit the contingencies in which military cooperation will occur. This definition based solely on common interests...Alliances are associations with a military or security purposes. This sets them apart from associations or regimes with economic and other purposes, such as OPEC or the European Union. ${ }^{25}$

Furthermore, Snyder highlights the four key features of formal alliances. He first argues that alliances differ according to size. Second, alliances may be unilateral, bilateral or multilateral, and third, alliances may be equal and unequal. ${ }^{26}$ In this context, he argues that alliances between states of similar strength tend to generate reciprocal and symmetrical obligations and expectation, whereas alliances between strong and weak states are characterized by asymmetrical expectations, if not obligations and most importantly, they tend to be dominated by the stronger member, which uses the alliance as a vehicle for asserting influence or control. Finally, alliances differ according to offensive or defensive purposes. ${ }^{27}$ However, as Snyder emphasizes, such a distinction is not as clear-cut as it might seem, since an ostensibly defensive alliance may hide offensive aims, and also because a state may have to undertake a tactical offensive in order to defend itself, an ally, or its interests effectively. ${ }^{20}$

George Modelski makes his own distinctive contribution to clarifying the "alliances" and "alignments" dichotomy by describing alignment as "a blanket term referring to all types of political cooperation", whereas "alliance" is specified as "military collaboration concerned with third power".29 Thus, in this respect Modelski's definition is rather different from Snyder's definition by inclusion of alliances into the tacit expectation of collaboration that the latter labels as "alignment" 30

The Penguin Dictionary of International Relations published in 1998 provides similar definition to Dingman and Snyder, according to which

$$
\begin{aligned}
& { }^{25} \text { Ibid. } \\
& { }^{26} \text { lbid., p.12 } \\
& { }^{27} \text { Ibid. }
\end{aligned}
$$$$
{ }^{28} \mathrm{lbid} \text {. }
$$

${ }^{29}$ Modelski, "Review: The Study of Alliances", p.774

${ }^{30}$ Snyder, Alliance Politics, p.6 "alliance" is "a formal agreement between two or more actors - usually states to collaborate together on perceived mutual security issues".31 Moreover, the above dictionary stipulates that:

By allying themselves together it is anticipated that security will be increased in one, some or all of the following dimensions: by joining an alliance a system of deterrence will be established and strengthened, by joining an alliance a defence pact will operate in the event of war, by joining an alliance some or all of the actors will be precluded from joining other alliances. ${ }^{32}$

Other important characteristics of alliance, as defined by the authors of the dictionary Graham Evans and Jeffrey Newnham, include joint military exercises, staff training and weapons procurement. ${ }^{33}$ Being allies also implies the need to support each other diplomatically in the conduct of their foreign policies. ${ }^{34}$ In addition, as Evans and Newnham indicate, alliances may be secret or open, bilateral or multilateral. ${ }^{35}$

On the other hand, influential academics such as Stephen M. Walt and Joseph S. Nye, Jr. offer somewhat different interpretations of "alliances". In their view, alliances do not necessarily have to be "formal". For instance, Walt defines alliance as "a formal or informal commitment for security cooperation between two or more states". ${ }^{36}$ Likewise, Nye describes alliances as "formal and informal arrangements that sovereign states enter into with each other in order to ensure their mutual security".37 However, Nye's view that states might ally for nonmilitary reasons and in particular, his assertion that "economic concerns might be another reason for an alliance ${ }^{\prime \prime 38}$ is not shared by majority of alliance theorists. According to these scholars, alliances are established purely for military or security

${ }^{31}$ Graham Evans and Jeffrey Newnham, The Dictionary of International Relations, (Penguin Books, 1998), p.15

${ }^{32} \mathrm{lbid}$.

${ }^{33} \mathrm{lbid}$

${ }^{35} \mathrm{lbid}$

${ }^{36}$ Stephen M. Walt, The Origins of Alliances, (Ithaca and London: Cornell University Press, 1987), p.12

${ }^{37}$ Joseph S. Nye, Jr., Understanding International Conflicts, (New York: Longman, Sixth Edition, 2007), p.69

${ }^{38} \mathrm{Nye}$, Understanding International Conflicts, p.69 
reasons. As Modelski argues "the act of voting together in an international conference does not establish an alliance between two countries, nor does the existence of alliance necessarily lead to common voting, for that depends on the issue on hand". ${ }^{39}$

As seen from the above, despite a lack of consensus among IR theorists on the exact definition of alliance (formal and informal, alliance vs. alignment taxonomy), the one point where a majority would agree is that "alliances are directly concerned first and foremost with defence matters". 40

Therefore, what is clear from the above is the fact that in conventional theory, "alliances" primarily imply formal associations of states for security or military purposes established against a third party. As Snyder emphasizes "alliances are aimed at states outside their own membership. This 'other' orientation points to a fundamental difference between alliances and most other international institutions or regimes". ${ }^{41}$

Furthermore, it seems that it is important to distinguish modern alliances, i.e. those of the Cold War era and today from their earlier variants. Military alliances or blocs that came into existence in the second half of the 20th century, in particular NATO and the Warsaw Pact were significantly different from those of the preceding periods such as Three Emperors Alliance of 1881, the Entente, and the Anti-Comintern Pact. The main difference between the above alliances lies in the fact that the latter were all simply results of political agreements between states and as such had no integrated military-political structure with permanent operational headquarters or a rapid reaction force, while their armies had no unification in armaments, not to mention a common military doctrine. ${ }^{42}$ The only requirement of signatory-countries was to enter a war if any of the parties was attacked. In contrast, NATO as well as the now-defunct Warsaw Pact (1955-1990) or today's Russian-dominated Collective Security Treaty Organization (CSTO) have all of the aforementioned attributes and are foremost designed for collective defense against external aggression. In this connection, it would be appropriate to quote Modelski who stated in

${ }^{39}$ Modelski, "Review: The Study of Alliances", .774

${ }^{40}$ Ibid., p.775

${ }^{41}$ Snyder, Alliance Politics, p.4

${ }^{42}$ On characteristics of a modern military alliance see NATO Handbook 2001, (Brussels: NATO Office of Information and Press, 2001), pp.42-57 his review of Osgood's book on NATO that "alliance is common defence and defence is use of military power."43

Nevertheless, it is important to emphasize that since the concept of "security" is undergoing significant transformation in the post-Cold War period, it will inevitably affect the structure and purposes of modern military alliances. For instance, when NATO was first conceived in 1949, its primary goal was to deter an eventual attack by the Soviet Union and its allies, whereas today this alliance is guided by a broader concept of security. Security encompasses not only military but also political, economic, social and environmental factors. ${ }^{44}$ As Marcel de Haas indicates, this comprehensive approach to security includes such aspects as free and fair elections; well-organized administrative, law-enforcement and judicial organs at national, regional and local levels; employment; housing; education and health services. ${ }^{45}$ Only when all of these dimensions of security are provided, then a stable and secure situation can be reached. This philosophy has been quiding NATO in its operations in Bosnia, Kosovo and Afghanistan. ${ }^{46}$ In this connection, de Haas notes that "during its operations in the former Yugoslavia in the 1990s, the Western alliance realized that its concept of security should include other aspects than military, in order to achieve a stable international security environment".47

While in conventional alliance theory, alliances are primarily taken as formal associations of states against a third party, due to the changing nature of "security" today, definitions are undergoing transformation. Modern alliances pay homage to a broader concept of security which in turn affects the nature and purposes of alliances. This in turn shows that the concept of "alliance" in its classical sense is becoming increasingly inapplicable in explaining the current tendencies surrounding the whole system of "alliances" and "alignments".

${ }^{43}$ Modelski, "Review: The Study of Alliances," p.771

${ }^{44}$ Marcel de Haas, The Shanghai Cooperation Organisation's Momentum towards a Mature Security Alliance, (The Hague: Netherlands Institute of International Relations, 2007), p.14 <http://www.clingendael.nl/publications/2008/20080100-cscp-haas-art-sm. pdf> (accessed on October 17, 2008)

${ }^{45} \mathrm{lbid}$

${ }^{46} \mathrm{lbid}$

${ }^{47} \mathrm{lbid}$ 
II. The Shanghai Five and the creation of the SCO

The SCO evolved from the Shanghai Five, regional mechanism of consultation between China, Russia and three Central Asian states, namely Kazakhstan, Kyrgyzstan and Tajikistan. At the time of its inception in 1996, the Shanghai Five had the aim to resolve the border disputes between the Soviet Union's successor states and China. This very term first emerged at the summit meeting of the five states in Shanghai in April 1996 during which China, Russia, Kazakhstan, Kyrgyzstan and Tajikistan concluded the Agreement on Deepening Military Trust in Border Regions. The following year heads of the aforementioned five states - Jiang Zemin, Boris Yeltsin, Nursultan Nazarbaev, Askar Akaev and Emomali Rahmonov signed in Moscow another landmark document entitled the Agreement on Reduction of Military Forces in Border Regions.

The third summit meeting of the Shanghai Five held in Almaty, Kazakhstan on July 3-4, 1998, marked a fundamental turning point in the development of relations among participant-states. Starting from that meeting Russia, Kazakhstan, Kyrgyzstan and Tajikistan ceased to represent one party in the Shanghai process - they came out as independent parties. The primary purpose of the meeting was to signify the agreements reached in 1996 and 1997, including resolving Soviet era issues and as one observer notes, to make the grouping "weightier and more solid"1"48. Moreover, the Almaty meeting witnessed the extension of the contents of themeetingsfrom discussing the issues related to confidence-building measures in border regions to the prospects of "developing comprehensive mutually beneficial cooperation in spheres of politics, security, diplomacy as well as trade-economic, cultural-humanitarian and other areas ${ }^{\prime \prime 9}$. Hence, the Shanghai Five's scope of activities went beyond the initial framework of collaboration resulting in new areas and new levels of cooperation.

The fourth and fifth summits of the Shanghai Five were held respectively in 1999 and 2000 in Bishkek and Dushanbe. The 2000 Dushanbe Summit was significant in that the Russian Federation was represented by the newly-elected President Vladimir Putin, and also through the participation of President Islam Karimov of Uzbekistan as a guest of the host state. As Chinese schola

${ }^{48}$ Vladimir Akimov quoted in Jefferson E. Turner, "What is Driving India's and Pakistan's Interest in Joining the Shanghai Cooperation Organization?", Strategic Insights, Volume IV, Issue 8 (August 2005)

${ }^{49}$ "History of development of Shanghai Cooperation Organisation", Sectsco.org, <http://www.sectsco.org/html/00035.html> (accessed on March 20, 2007)
Zhao Huasheng underlines, this meeting became another significant step in the Shanghai Five's evolution from a structure with a limited number of participants, to having an "organizational" character ${ }^{50}$. As a result of the summit, the heads of states agreed to include the issues pertaining to prevention of military threats, conducting joint military exercises as well as exchange of experience in various fields into the framework of cooperation. Furthermore, it was decided at the summit to regularly organize meetings of defense ministers as well as of senior officials in charge of state security, justice, border protection and customs and to take into consideration the possibilities of holding joint field training to combat terrorism and natural disasters. In this respect, the joint communique released from the summit called for establishment of a counter-terrorism center in Bishkek, Kyrgyzstan "to jointly combat national separatism, international terrorism and religious extremism ${ }^{\prime \prime 1}$. As Benjamin Goldsmith argues, "at the 2000 summit in Dushanbe, Tajikistan, the Shanghai Five ceased to be an organization bound by a common conflict and was transformed into an organization bound by common interests"s2.

Having successfully solved the problems inherited from the Soviet era, members of the Shanghai Five went one step further. At the summit meeting held in Shanghai in June 2001 the Shanghai Five was transformed into the Shanghai Cooperation Organization which included the five founding members, plus Uzbekistan. The fact that Uzbekistan, a country which has no common border with China, joined the SCO implied that members of this organization found a common area of interest that extended beyond the initial aims of the Shanghai Five. All six members of $\mathrm{SCO}$ are to greater or lesser degree authoritarian regimes, bound by common interest to suppress radical Islamist movements in their respective territories ${ }^{33}$. Each has domestic problems with militant Islamist groups: Chechen separatists in the Northern Caucasus (although somewhat diminished in the past four years) have been fighting a bloody war against Moscow for over a decade; the East Turkestan Islamic Movement in Chinese

${ }^{50}$ Zhao Huasheng, Kitai, Tsentral'naya Aziya i Shankhaiskaya Organizatsiya Sotrudnichestva [China, Central Asia and the Shanghai Cooperation Organization], Carnegie Moscow Center Working Paper 5/2005, (Moscow: Carnegie Moscow Center, 2005, p.6 <http://www.carnegie.ru/en/pubs/workpapers/73064.htm> (accessed on August 08,2008

${ }^{51}$ Turner, "What is Driving India's and Pakistan's Interest in Joining the Shanghai Cooperation Organization?"

s2 Goldsmith, "Here There Be Dragons: The Shanghai Cooperation Organization" ${ }^{53} \mathrm{lbid}$ 
Xingjian-Uighur Autonomous Region is fighting to create an independent state; the Islamic Movement of Uzbekistan and Hizb-ut-Tahrir, which were aided by the Taliban been receiving transnational support, Russia and China deemed it important to develop regional cooperation on counter-terrorism, while the smaller members have sought to eliminate the threat these groups posed to their regimes ${ }^{55}$.

The establishment of the SCO at the Shanghai summit meeting was followed by a series of policy decisions and conventions. The Declaration on the Establishment of Shanghai Cooperation Organization identified the newlyfounded organization's objectives as follows:

strengthening mutual trust and good-neighborly friendship among the member states; encouraging effective cooperation among the member states in political, economic and trade, scientific and technological, cultural, educational, energy, communications, environment and other fields; devoting themselves jointly to preserving and safeguarding regional peace, security and stability; and establishing a democratic, fair and rational new international and political order ${ }^{56}$.

The communique on arms control reaffirmed the SCO's support for the 1972 Anti-Ballistic Missile (ABM) treaty and opposition to the U.S. National Missile Defense (NMD) program, as well as declaring Central Asia as a nuclear free zone ${ }^{57}$. The SCO member states also reiterated their support for the United Nations Charter and pledged non-interference in each other's internal affairs ${ }^{58}$. Similarly, they indicated that there was interest in starting a dialogue with the ASEAN Regional Forum (ARF $)^{59}$. The heads of states also agreed to accelerate institutionalization of cooperation mechanisms in areas of border security, confidence-building, antiterrorist, separatist and extremist activities, economic cooperation, and social/cultural exchanges, as well as a mechanism for dispute resolution among SCO partners.

The highlight of the summit meeting was the Shanghai Convention on fighting Terrorism, Separatism and Extremism. Alyson J. K. Bayles and Pal Dunay

\section{${ }^{54} \mathrm{bid}$.}

${ }^{56}$ The Declaration on the Establishment of Shanghai Cooperation Organization, June 15, 2001, Shanghai, Sectsco.org, http://www.sectsco.org/html/00088.html (accessed on March 25, 2007)

${ }^{57}$ Turner, "What is Driving India's and Pakistan's Interest in Joining the Shanghai Cooperation Organization?

${ }^{58} \mathrm{lbid}$ underline that the SCO's founding documents signal the special interest of the member states in fighting what they defined as "terrorism, separatism and extremism" ${ }^{\prime \prime 0}$. Leaders of the SCO member states take credit that members of the grouping had started to work on the draft of the above-said Convention two years before the September 11 terrorist attacks in New York ${ }^{61}$. In this context, Alexander Lukin argues that the single definitions of such terms as "terrorism", "separatism" and "extremism" contained in the Convention, is of particular importance since the absence of consensus on terminology serves as one of main obstacles to international cooperation against these phenomena ${ }^{62}$. For instance, in the eyes of some people, Chechen separatists and Palestinian participants of intifada are terrorists and extremists, whereas for others they are freedom fighters against imperialism and for national liberation. In addition, the Convention continued to focus the SCO on regional security issues, while downplaying any notion of the $\mathrm{SCO}$ as a military alliance ${ }^{63}$.

After September 11, 2001 the SCO started to evolve more rapidly. The US deployed its troops to several Central Asian states and established bases from which to operate against Al Qaeda's main network in Afghanistan. While Russia and China recognized the U.S. right to respond against radical Islamist groups which were the sources responsible for the terrorist attacks, the establishment of U.S. airbases in Uzbekistan and Kyrgyzstan raised concerns ${ }^{64}$. At the 2002 Saint-Petersburg summit meeting, the member states of SCO adopted The Charter of Shanghai Cooperation Organization which identified goals, principles and basic directions of the organization.

${ }^{60}$ Alyson J.K. Bayles and Pal Dunay, "The Shanghai Cooperation Organization as a regional security institution", The Shanghai Cooperation Organization, SIPRI Policy Paper No.17, (Stockholm: Stockholm International Peace Research Institute, May 2007), p.4

${ }^{61}$ Alexander Lukin and Alexei Mochulsky, "Shankhaiskaya organizatsiya sotrudnichestva: strukturnoye oformleniye i perspektivy razvitiya" [Shanghai Cooperation Organization: structural formation and perspectives of development], Analyticheskiye Zapiski, no. 2(4) (Feb.2005), p. 8

${ }^{62}$ Alexander Lukin, "Shankhaiskaya organizatsiya sotrudnichestva: chto dal'she?" [Shanghai Cooperation Organization: what lies ahead?], Rossiya v global'noi politike, No.3, (May-June 2007), <http://www.globalaffairs.ru/numbers/26/7700.html> (accessed on April 03, 2007)

${ }^{63}$ Turner, "What is Driving India's and Pakistan's Interest in Joining the Shanghai Cooperation Organization?"

${ }^{64} \mathrm{lbid}$. 
In addition, the Charter lists several basic principles of international law as the foundations of theorganization, including the sovereign equality of states and the rejection of hegemony and coercion in international affairs ${ }^{65}$. Furthermore it contained a statement that the SCO is "not directed against other States and international organizations" $\mathrm{s}^{\prime \prime}$

The May 2003 summit meeting in Moscow concluded the institutional organization of the SCO. The most significant actions taken by the SCO heads of state was their decisions to establish the SCO headquarters in Beijing and launch activities of the Regional Anti-Terrorist Structure (RATS) ${ }^{67}$ The Secretariat of the SCO started to function in Beijing in 2004, while RATS was launched the same year with the base in Tashkent, Uzbekistan. Zhang Deguang of China was the first Secretary-General of the SCO, and the current Secretary-General Bolat Nurgaliev of Kazakhstan has been serving since 2007. The SCO Secretariat has a permanent staff of 30 and its initial budget was $\$ 2.6$ million $^{68}$. The remainder of the SCO's 2004 budget of $\$ 3.1$ million was allocated to RATS ${ }^{69}$.

As the process of SCO's evolution went further, four states, namely Mongolia, Iran, India and Pakistan were admitted to the SCO as observers in 2004 and 2005, respectively. Although Afghanistan does not have an official observer status in the $\mathrm{SCO}$, it works in close collaboration with the organization, and its President Hamid Karzai has been regularly attending the SCO summit meetings. Thus, as of today the SCO encompasses all countries in or bordering the Central Asian region

III. The Shanghai Cooperation Organization participants and their interests

3.1 China

The very fact that the SCO's predecessor, the Shanghai Five was created with China on one side and the Soviet Union's successor states on the other made

${ }^{65}$ See The Charter of Shanghai Cooperation Organization, June 07, 2002, SaintPetersburg, Sectsco.org, http://www.sectsco.org/news_detail.asp?id=96\&LanguagelD=2 (accessed on August 20, 2008)

${ }^{66} \mathrm{lbic}$

${ }^{67}$ Turner, "What is Driving India's and Pakistan's Interest in Joining the Shanghai Cooperation Organization?"

${ }^{68}$ Bayles and Dunay, "The Shanghai Cooperation Organization as a regional security institution", p.5
Beijing its natural nucleus as the grouping was gradually taking the shape of multilateral organization. As a number of analysts and scholars indicate, at its heart the $\mathrm{SCO}$ is the Chinese project ${ }^{70}$ and as such it serves as the matter of great pride for the nation. In particular, a leading US expert on China, former Deputy Assistant Secretary of State, Susan L. Shirk contends that "Pride of ownership makes the Shanghai Cooperation Organization (SCO) China's favorite regional organization and useful precedent for expanding its role in other organizations ${ }^{\prime \prime 1}$. In the official Chinese view, the two focal points of China's regional cooperation framework are the SCO and ASEAN Plus Three ${ }^{72}$.

In this respect, it would be appropriate to note that China's embrace of multilateralism starting from mid-1990's is a remarkable phenomenon that can be witnessed in other fields of the country's diplomacy, including notably its relations with South East Asian countries and its growing contributions to UN peacekeeping missions ${ }^{73}$. For instance, Chinese scholar Pan Guang asserts that it "symbolizes the entry of Chinese diplomacy into a new stage, with an orientation towards multilateral cooperation"174. Through instrumental use of multilateral methods, China has been conducting a policy to convince its immediate neighbors and surrounding countries that China's constructive, responsible and non-threatening behavior will be beneficial for them.

In the case of the SCO, this multilateral organization represents an important avenue for China in developing fruitful cooperation with its former adversary - Russia - helping it avoid future conflicts and frictions as well as establishing an orderly framework for their coexistence in Central Asia. In particular, if considered from a geopolitical perspective, the interests

${ }^{70}$ See for example Goldsmith, "Here There Be Dragons: The Shanghai Cooperation Organization", Susan L. Shirk, "China's Multilateral Diplomacy in the Asia-Pacific", Before the U.S.-China Economic and Security Review Commission "China as an Emerging Regional and Technology Power: Implications for U.S. Economic and Security Interests", February 12-13, 2004, Uscc.gov,

http://www.uscc.gov/hearings/2004hearings/written_testimonies/04_02_12wrts/ shirk.htm (accessed on August 14, 2008

${ }^{2}$ Susan L. Shirk, China, Fragile Superpower, (Oxford University Press, 2007), p.120

${ }^{72} \mathrm{lbid}$

${ }^{73}$ Bayles and Dunay, "The Shanghai Cooperation Organization as a regional security institution", p.13

"Pan, "A Chinese Perspective on the Shanghai Cooperation Organization", p.45 
of two competing powers, China and Russia could potentially clash in Central Asia. As such, this might be an important stimulus for collaboration between two . that brings together and balances the interests of China and Russia. Moreover, it has provided opportunities for both sides to hold regular consultations and meetings in various fields at different levels which in turn helps better understand each other and enhances their mutual trust.

As regards Central Asian states, since their independence China has not encountered any difficulties in developing bilateral relationships with them. But nevertheless, unt wich linked China with Centrasi as a whole ${ }^{75}$. Although the abs no adverse effect on development of bilateral relations, it limited to a certain extent resolution of common regional problems ${ }^{76}$. The SCO has created conditions for developing multilateral cooperation and enabled China to hold dialogue with all countries in the region as a group.

However, as Bayles and Dunay rightly point out, in all those aforementioned cases the choice of diplomatic methods does not imply that there are no hard core security issues at stake for China". In the SCO's case, the suppression of the "three evils" of terrorism, separatism and extremism represents an important objective for China. The main target of the Chinese anti-terrorism campaign is the East Turkestan Islamic Movement (ETIM) which advocates the independence of Xinjiang and is believed to have close connections with the Al Qaeda terrorist network ${ }^{78}$. Thus, after the September 11 terrorist attacks on the USA, China managed to get ETIM included into some Western lists of terrorist organizations ${ }^{79}$.

The problem of "national separatism" in Xinjiang-Uighur Autonomous Region has a direct relevance to the Central Asian states. This is linked with geographical, ethnic and confessional closeness as well as with the commonality of centuries-long historical processes in Xinjiang and Central Asia. Xinjiang borders three of Central Asian states as well as such Islamic flashpoints as Kashmir and

${ }^{75}$ Zhao, Kitai, Tsentral'naya Aziya i Shankhaiskaya Organizatsiya Sotrudnichestva, p.29 ${ }^{76}$ lbid.

"7 Bayles and Dunay, "The Shanghai Cooperation Organization as a regional security institution", p.13

${ }^{78} \mathrm{See}$ Pan, "A Chinese Perspective on the Shanghai Cooperation Organization", p.46; and Goldsmith, "Here There Be Dragons: The Shanghai Cooperation Organization"

${ }^{79}$ Bayles and Dunay, "The Shanghai Cooperation Organization as a regional security institution", p.14
Afghanistan. From the former Soviet republics of Central Asia, it shares the longest border with Kazakhstan (over 1,700 km). The Central Asian region is also a home to a well-established Uighur Diaspora, the largest of which lives in Kazakhstan (over 220 thousand people), and which occupies in terms of number, the third place in the country and the second in the world after the PRC itself fo $^{8}$.

Due to their large number, by supporting the idea of a "struggle for independence", representatives of Uighur populations of the Central Asian states, have expanded the social base of protest and thereby provided fertile ground for the rise of ethnic separatism in Xinjiang ${ }^{81}$. In addition, external factors have undoubtedly played their part in the growth of separatism in China. The collapse of the Soviet Union, intensification of ethnic conflicts in the post-Soviet space as well as in some Eastern European countries coupled with the revival and consolidation of the Islamic world and internationalization of terrorism have all awakened dormant socio-economic and political forces that led to re-emergence of Uighur separatism. Thus, the early 1990s saw the explosion in numbers of overseas Uighur organizations which not only had established ties with each other but also with underground separatist groups in Xinjiang ${ }^{82}$.

The above-mentioned tendencies serve as the matter of grave concern for Chinese leadership which to a large extent played an important role in the Chinese active participation in the SCO. Geographic proximity of Xinjiang-Uighur Autonomous Region to Central Asia is certainly one of main reasons for China's membership in the SCO. To sum up, one of the most important reasons for China's initiation and involvement with the SCO is its genuine interest in having guarantees of unequivocal support from its neighboring countries for the principle of territorial integrity of the PRC.

A second major interest which China has in the SCO is what Zhao defines as the "guarantee that Central Asia is a stable strategic rear" of China ${ }^{83}$. As he further elaborates:

${ }^{80} \mathrm{~K}$. Khaphizova, "Separatizm v Sin'dzyan-Uigurskom avtonomnom raione Kitaya: Dinamika i potentsial vliyaniya na situatsiyu v Tsentral'noi Azii" [Separatism in XinjiangUighur Autonomous Region of China: Dynamics and Potentials of its Impact on the Situation in Central Asia], Tsentral'naya Aziya i Kavkaz, No.1, (2003), <http://www.ca-c. org/journal/rus-01-2003/01/khaprimru.shtml> (accessed on 09 August 2008)

${ }^{81}$ lbid.

${ }^{82} \mid \mathrm{bid}$

${ }^{83}$ Huasheng Zhao, "Central Asia in China's Diplomacy", in Eugene Rumer, Dmitri Trenin and Huasheng Zhao, Central Asia, Views from Washington, Moscow and Beijing (Armonk, New York, London, England: M.E. Sharpe, 2007), p.159

Number 15-16, 2008- 2009 
Given this objective of strategic security, China must prevent the formation of any real and potential strategic threat, ensure that the region not be controlled by any country or state group hostile to China, oppose militarization of the region and formation of any political and military group directed against China ${ }^{84}$.

This objective belongs to the sphere of the national interests of the PRC, but it can also be included into the matters of the country's grand strategy and geopolitics. Therefore, its content is somewhat different from the earlier mentioned objective of providing state security through combating ETIM. From this angle Central Asia is acquiring a new place in the foreign policy of the PRC, representing different strategic functions and interests.

In particular, from the strategic perspective, the southern and eastern directions are considered as having the utmost importance in the country's foreign policy. According to Beijing, the most important and difficult task of foreign policy strategy of the PRC is to prevent Taiwan from gaining formal independence and therefore, as Zhao stresses "it needs to constantly prepare for a possible showdown with Taiwan should the island seriously challenge the mainland"s5. He further explicitly states that "the US hidden or open, direct or indirect support of Taiwan as well as its confrontational policy aimed at containing China's rise" might lead to strategic conflict between China and the US, and therefore, as Zhao argues, "it is essential to provide peace and stability in other strategic directions ${ }^{\prime \prime 66}$. Thus, it is in the Chinese strategic interest that Central Asia serves as the "stable strategic rear of China".

In this connection, it is worth of mentioning that the 2000 Dushanbe Declaration of the Shanghai $\mathrm{Five}^{87}$ which precipitated the formation of the SCO in 2001, included two references to Taiwan, which one could assume to have little relevance to the Central Asian region ${ }^{88}$. This clearly shows that the highest priority for China is the Taiwan issue and thereby substantiates the earlier-mentioned designation of Central Asia in the Chinese foreign policy as the "stable strategic rear of China".

${ }^{84} \mathrm{lbid}$.

${ }^{85}$ Zhao, Kitai, Tsentral'naya Aziya i Shankhaiskaya Organizatsiya Sotrudnichestva, p.33

${ }^{86} \mathrm{lbid}$

${ }^{87}$ Dushanbe Declaration by the Heads of State of the Republic of Kazakhstan, of the People's Republic of China, of the Kyrgyz Republic, of the Russian Federation, and of the Republic of Tajikistan, Shanghai Five, June 6, 2000, Mid.ru, <http://www.In.mid. ru/Bl.nsf/0/A69BB7197B47EC174325699C003B5F9D?OpenDocument> (accessed on March 20, 2007)

${ }^{88}$ Goldsmith, "Here There Be Dragons: The Shanghai Cooperation Organization"
Third, Central Asia is becoming increasingly important to China for achieving its goal to intensify its economic development and exert control over the region's rich oil and natural gas resources. Rapid economic growth is high on the Chinese agenda and one of the main problems facing China today is the enormous gap in development between its eastern and western regions. Therefore, maintaining good relations with the Central Asian countries - members of the $\mathrm{SCO}$ is seen as an important factor for development of China's western region. The 2000 Dushanbe Declaration called on Central Asian states to take active part in developing the western region of China.

On the other hand, trade with China is important for all Central Asian states. Today China accounts for around 10 percent of Central Asia's trade volume ${ }^{89}$. As far as China is concerned, in economic terms, Central Asia has not had a great overall impact on the Chinese economy, for its share of China's total trade volume is small. ${ }^{90}$ In particular, in 2005 when total trade reached more than 1,400 billion U.S. dollars, trade with Central Asia totaled just slightly more than 8.7 billion U.S. dollars ${ }^{91}$. Thus, both in absolute or relative terms, trade with Central Asian states represents only a small portion of China's total foreign trade.

As Zhao concludes, "from Beijing's perspective, Central Asia is of economic importance primarily with respect to the development of the country's Northwest, especially Xinjiang, the main beneficiary of trade with Central Asia." 92

Fourth, Central Asia's rich mineral resources are becoming increasingly important for China's rapid economic development, which is of high strategic importance for the nation. Energy represents an important component of China's economic cooperation with Central Asian states, and Beijing deems it important to insure access to rich Caspian oil and gas reserves. For instance, China has become a major investor in Kazakhstan's oil industry with its companies starting their operations in that country since 1997. ${ }^{93}$ The two countries are jointly building a new 2,900-kilometer

\section{${ }^{89}$ Zhao, “Ce}

${ }^{90} \mathrm{lbid}$.

${ }^{9}$ Ibid.

${ }^{92} \mathrm{lbi}$

${ }^{93}$ Kirill Nourzhanov, "Caspian oil: geopolitical dreams and real issues", Australian Journal of International Affairs, Vol.60, No.1, (March 2006), p.62 
oil pipeline which will run from Atyray through Kenkiyak, on to Kumkol, Atasu, and then Alashankou on the Kazakh-Chinese border ${ }^{94}$. By the end of 2005 two stretches were already operational 95 In addition, in August 2005 the state-owned China National Petroleum Company (CNPC) bought the Canadian company PetroKazakhstan, which has the second largest proved oil reserves in Kazakhstan, and in December 2006 China's CITIC Group purchased the Kazakhstan oil assets of the Canadian company Nations Energy for USD 1.9 billion, the third largest overseas oil acquisition made by a Chinese company. ${ }^{96}$

Hence, all of the above-stated evidence demonstrates that the cooperation on the part of Central Asian states as well as the over-all stability in the region is becoming essential for the attainment of China's long-term strategic interests.

\subsection{Russia}

Russia represents one of the two predominant members of the SCO alongside China. As the sovereign of the most of the Central Asian region for over a century, it has extensive historical and cultural ties to the region and a strong belief that Central Asia is its natural sphere of influence. ${ }^{97}$ Throughout almost two centuries of Moscow's rule in Central Asia, especially during the 70 year-Soviet period, close bonds were formed between Russia and Central Asian nations in the areas of politics, economy, defense, culture, language, social life and ideology. The basis of Russia's interests in the Central Asian region today thus lies in its desire to preserve these special relations.

${ }^{94}$ Martha Brill Olcott, The Shanghai Cooperation Organization: Changing the "Playing Field" in Central Asia, Testimony before the Helsinki Commission, (September 26, 2006), p.3,

<http://wwwcarnegieendowmentorg/files/MBO0906 pdfs (accessed on March 20, 2007)

${ }_{95} \mathrm{bid}$

${ }^{96}$ See "CNPC secures PetroKazakhstan bid", BBC News, 26 October 2005, <http:// news.bbc.co.uk/2/3723249.stm> (accessed on October 07, 2008) ; and Xinhua, "China's CITIC Group acquires Kazakhstan oil assets for 1.91 bln US dollars", People's Daily (English edition), 1 January 2007

${ }^{97}$ Moscow ruled most of the Central Asian region first during the period of the Russian Empire from the late 19th century until October Revolution of 1917 and then later during the existence of USSR from 1922 until December 1991
Given the long history of Russia's predominance in Central Asia, it is no surprise that it would not be in Russian interests to let China gain overwhelming prominence there. Therefore, as Bayles and Dunay convincingly argue "in Russia's relations with the Central Asian states, the SCO plays a supplementary and consolidating role ${ }^{\prime \prime 98}$. Although Russia is prepared to cooperate with Central Asian republics within the framework of the SCO, it prefers to exercise its traditional influence on Central Asian nations through the Commonwealth of Independent States (CIS) and Collective Security Treaty Organization (CSTO) of which China is not member. Compared to SCO, Russia holds much greater influence on Central Asian nations within these organizations, giving it a stronger interest in projecting its power through them.

However, this does not imply that Russia has no interest in the SCO whatsoever. As Russian scholar Mikhail Troitskiy asserts "the SCO has multiple meanings and purposes for Russia" ${ }^{99}$. First, the creation of the SCO in 2001 which coincided with the conclusion of the bilateral Treaty on Good Neighborliness, Friendship and Cooperation, further strengthened the Russo-Chinese strategic partnership, first proclaimed in 1996 during the Russian President Boris Yeltsin's visit to China. In this context, it could be even argued that to a larger part the SCO is based on the strategic partnership between Russia and China.

As Thomas S. Wilkins rightly points out, "this partnership is primarily founded upon a number of mutual interests not shared values"100 Both Russia and China have a strong interest in resisting domination of the international system by the U.S and its allies. Bobo Lo argues that "The relationship is clearly established on the basis of common interest rather than "shared values" or ideological stereotypes... this is a realist (and even

Bayles and Dunay, "The Shanghai Cooperation Organization as a regional security institution", p.13

${ }^{99}$ Mikhail Troitskiy, "A Russian Perspective on the Shanghai Cooperation Organization", The Shanghai Cooperation Organization, SIPRI Policy Paper No.17, (Stockholm: Stockholm International Peace Research Institute, May 2007), p.33

${ }^{100}$ Thomas S. Wilkins, Russia's 'Strategic Partnerships:' Building A Framework For Analysis, (San Francisco: University of San Francisco, Center for the Pacific Rim, November 06, 2007), p.18<http://www.allacademic.com//meta/p_mla_apa_research_ citation/2/5/4/0/3/pages254031/p254031-1.php> (accessed on October 07, 2008) 
cynical) union of interests, not a love-in"101. Both of them are concerned with what they perceive as negative tendencies in the development of the international situation. According to the former Russian Foreign Minister Igor Ivanov:

Russian-Chinese cooperation has a specific significance in such key areas as the raise of prestige and role of the United Nations, assertion of the primacy of international law in world affairs, maintenance of strategic stability and above all, preservation of the ABM Treaty as well as creation of the just and equitable international economic order. ${ }^{102}$

It is evident that the above-stated Russian-Chinese objectives as reflected by Igor Ivanov, derive from their mutual concern with what they consider as the emerging tendency designed to dismantle the existing system of the international law and creation of the centre of international politics excluding the UN and without participation of China and Russia. ${ }^{103}$ In particular, what brings together Moscow and Beijing above all is the danger of US strategic assertiveness, manifested in such actions as the NATO air strikes against Yugoslavia over Kosovo in 2000, the 2003 invasion of Iraq, the expansion of NATO, alliance with Japan and National Missile Defense (NMD) program. In this sense, it is consistent with realist notions of "balancing against threats". 104

Nevertheless, it is important to emphasize the fact that today's RussoChinese strategic partnership is nothing like Sino-Soviet alliance of a more than half a century ago. Rather than a relic of the Cold War, the strengthening relationship between China and Russia is driven by a complex set of shared interests and different priorities. As noted earlier, Russia and China explicitly avoid the trappings of a formal alliance. Not wishing to antagonize the West by creating an explicit Russo-Chinese alliance and trigger a new Cold War, both parties have been deliberately emphasizing that their alignment including their collaboration within the SCO is not aimed at any "third party".10.5

${ }^{101}$ Bobo Lo, “The Long Sunset of Strategic Partnership: Russia's Evolving China Policy”. International Affairs, Vol.80, No.2 (2004), p.304

${ }^{102}$ Igor Ivanov quoted in Alexander Lukin and Sergei Sanakoev, "Rossiiskii podhod k Kitayu na rubezhe vekov: problemy i resheniya" (Russia's Approach towards China at the threshold of centuries: problems and solutions], Analyticheskiye Zapiski, no. 5(7) (Apr.2005),

${ }^{103} \mathrm{lbid}$.

${ }^{104}$ See Walt, The Origins of Alliances, p.5, and pp.21-26

${ }^{105}$ Wilkins, Russia's'Strategic Partnerships:'Building A Framework For Analysis, p.19
For instance, in an interview on 4 June 2002, to the Chinese People's Daily newspaper Russia's then-President and the current Prime Minister Vladimir Putin explicitly stated that "SCO is not military bloc but an organizatio which can play an important role in promoting development in Asta" In this connection, one needs to bear in the mind the differences between "alignments" and "alliances" discussed in the Chapter Two.

Second, while cooperating with the US in Central Asia during antiTaliban campaign of 2000-2001, Russia found the SCO as a useful means to balance its relationship with Washington by strengthening ties with China and Central Asian states. ${ }^{107}$ Finally, as the Kazakh analyst Zakir Chotaev underlines:

The SCO is a structure that allows Moscow to control and limit Beijing's activities in Central Asia... This Organization [is valued for] the conditions and opportunities it provides for developing multilateral relations [with Central Asian states], for enhancing regional security with participation of China and for coordinating SCO members 'foreign policies.'108

At the same time, Chotaev considers that "Russia does not hinge its efforts to expand influence in Central Asia on SCO mechanism".109 The last point is particularly important as it clearly shows that China and Russia will fall short of forming a military alliance. As mentioned earlier, Russia's main tools of collaboration with the former Soviet republics including Central Asian states are CIS and CSTO of which the latter serves as the focal point for defense cooperation in the most of former post-Soviet space. The CSTO includes Armenia and Belarus along with Russia and the four Central Asian states of Kazakhstan, Kyrgyzstan, Tajikistan and Uzbekistan. Although several steps have been taken to establish links between the SCO and CSTO, as Troitskiy emphasizes, "CSTO-SCO contacts remain limited overall, and this seems to be in line with Russia's interests in and vision of the SCO".110 What is more, while the CSTO is designed as a traditional defense arrangement, the SCO explicitly renounces any ambition to develop

${ }^{106}$ Vladimir Putin quoted in Troitskiy, "A Russian Perspective on the Shanghai Cooperation Organization", p.30

${ }^{107} \mathrm{lbid}, \mathrm{p}$. 33

${ }^{108}$ Zakir Chotaev quoted in Ibid. pp 33-34

${ }^{109}$ bid. p.34

${ }^{110} \mathrm{lbid}$. 
military cooperation apart from intelligence sharing and limited joint exercise, primarily in the sphere of counter-terrorism. ${ }^{111}$ Moreover, the and collective decision elaborates, "Russia has to accept the role of a junior founding partner and share influence with China". ${ }^{113}$

In addition, the fact that the Central Asian states are becoming increasingly inclined to use the SCO as a buffer to balance Russian and Chinese influence in the region is certainly not in the long-term Russian interest. As Martha Brill Olcott observes "It is the one meeting place where Russia sits down with the leaders of these states and is immediately confronted with a strong leader of nearly equal influence and with very different economic goals".114

There is little evidence to suggest that Russia is eager to share the intelligence collected by Moscow, or the Central Asian countrie with Beijing In this respect, Olcott emp establishments of Central Asian countries are collaborating more closely with Moscow that has been the case any time since their independence. ${ }^{115}$ Given the fact that historically Russia and China have never been true allies except the brief period starting from the establishment of the People's Republic of China in 1949 until the outbreak of Soviet-Chinese ideological conflict at the beginning of 1960s, suspicion of each other's motives and intentions simply run too deep.

Similarly, in the economic field Russia and China do not completely trust each other. For instance, Russia is more inclined to promote its interests in Central Asia through the Eurasian Economic Community (EURASEC), which includes Kazakhstan, Kyrgyzstan, Tajikistan and Uzbekistan as well as Belarus.116 Given China's increasing economic leverage over Central Asia, Russia is interested in establishing a free-trade ${ }^{111} \mathrm{lbid}$

112 bid.

${ }^{113} \mathrm{bid}$ bid.

${ }^{114} \mathrm{Olcott}$, The Shanghai Cooperation Organization: Changing the "Playing Field" in Central Asia, p.11

${ }^{116}$ Troitskiy, "A Russian Perspective on the Shanghai Cooperation Organization", p.35 zone with its Central Asian partners through EURASEC rather than the $\mathrm{SCO}{ }^{117}$ In this connection, Lukin notes that China's aggressive and egoistic stance focused on promoting its trade interests without taking into consideration the interests of its other partners puts obstacles to economic cooperation within the framework of SCO..$^{118}$

In conclusion, as Troitskiy rightly observes "as the leading power in the CSTO and EURASEC and as member of the SCO, Russia faces a dilemma". ${ }^{119}$ Should it focus on the military-strategic component of cooperation or rather on "soft" security and economics? In the former case, the SCO might overshadow the CSTO or at least create confusing choices (with unpredictable outcomes) for Central Asian states. ${ }^{120}$ In the latter case, China may gain additional leverage within the SCO - given China's increasing economic clout and its ability to make a way into Central Asia through both small-scale trade and large state-supported investment programs which might lead to declining of the importance of EURASEC. ${ }^{121}$

\subsection{Central Asian member states}

In terms of geography, Central Asian states are located between Russia and China. Sandwiched between these two powers, the Central Asian member-states of SCO are compelled to maintain balance of power in the region through conduct of multi-vector strategy of balancing. Hence, for Central Asian states the SCO serves mainly as a structure that allows balancing first, between the old hegemon Russia and the expanding power of China, and second, between these powers and the states and institutions of the West. ${ }^{122}$ In this context, the principal value of the SCO for the Central Asian states lies in the fact that it enables them, at least formally, "to take part in generating regional approaches to cooperation and security on an

${ }^{117}$ lbid.

${ }^{118}$ Lukin, "Rossiya i ShOS", p.7

"119Troitskiy,"A Russian Perspective on the Shanghai Cooperation Organization", p.35

${ }^{120} \mathrm{lbid}$

${ }^{122}$ Bayles and Dunay, "The Shanghai Cooperation Organization as a regional security institution", p.14 
equal basis with the larger regional powers ${ }^{\prime 123}$. Ruslan Maksutov contends that "it is an opportunity that Central Asia has not had before in modern times".24

As noted above, the SCO has provided the Central Asian states with mple opportunities to balance the influence of Russia and China in the region. In particular, Bayles and Dunay note that by being able to take their distinctive positions on security issues "in a forum with China present, not to mention the far-flung observer states, helps to offset the subordinate role that these countries have been obliged to accept in practice in the post-Soviet CSTO, where military cooperation is inexorably dominated by Russia".25 In this connection, Olcott recalls that one Central Asian foreign minister confided at an off-record meeting at the Carnegie Endowment for Peace that the biggest advantage his country gained from membership in the SCO was that it could use China to bolster its position vis-à-vis Russia, when those in his national capital disagreed with those in Moscow. ${ }^{126}$

Moreover, the creation of the SCO has not strained the Central Asian countries' relationships with the US, other Western countries and multhan in June 2001 that Kyrgyzstan and Uzbekistan agreed to provide military facilities to the U.S.-led anti-terrorist coalition's operations in Afghanistan; and Kyrgyzstan still hosts the U.S. air base notwithstanding the SCO's 2005 Astana Declaration. ${ }^{127}$

${ }^{123}$ Ruslan Maksutov, The Shanghai Cooperation Organization: A Central Asian Perspective, SIPRI Project Paper, (Stockholm: Stockholm International Peace Research Institute, August 2006), p.4, <http://www.sipri.org/contents.worldsec/eurosec.html> (accessed on May 07, 2007)

${ }^{124}$ lbid.

${ }^{125}$ Bayles and Dunay, "The Shanghai Cooperation Organization as a regional security institution", p.14

${ }^{126}$ Olcott, The Shanghai Cooperation Organization: Changing the "Playing Field" in Central Asia, p.11

${ }^{127}$ Following the US strong criticism of the Uzbek Government's heavy-handed crackdown on popular protests at Andijan in May 2005 relations between US and Uzbekistan, which until then had been considered as the US "strategic partner", severely deteriorated. This in turn led the SCO member states at Astana Summit held in July 2005 to issue a declaration calling for members of the US-led international anti-terrorism coalition to set a timeframe for withdrawal of their forces from the territory of the SCO member countries, a move apparently initiated by Uzbekistan and enthusiastically supported primarily by Russia. Not long after the said summit, the US base at Karshi-Khanabad in Uzbekistan was closed down.
Under the auspices of OSCE and NATO's Partnership for Peace (PFP) programs, the Central Asian states have been receiving substantial Western aid and advice for military reform and technical interoperability as well as for the development of defensive, intelligence-gathering and enforcement capabilities against various "new threats". ${ }^{128}$

In addition, the Central Asian states, most notably Kazakhstan, have put forward and started to realize independent security initiatives such as the Conference on Interaction and Confidence-building measures in Asia (CICA) and the establishment of stronger ties with other outside actors not previously involved in the Central Asian region. ${ }^{129}$ Bayles and Dunay consider CICA as another "effort to dilute Russian dominance".130 In this regard, Kazakhstan's foreign policy can be considered as the most vivid example of Central Asian "balancing". In a July 2006 speech made at the Central Asia-Caucasus Institute, then-Kazakh Foreign Minister and the current President of the Senate of the republic, Kassymzhomart Tokaev, stated that his country would "work to keep the SCO universal and well-balanced"131 In January 2006 an Individual Partnership Action Plan between Kazakhstan and NATO was signed, making Kazakhstan the first Central Asian state to conclude such an accord with the above organization. ${ }^{132}$ And in September of the same year, Kazakhstan's President Nursultan Nazarbaev visited the US, seeking a wide-ranging "strategic partnership" with Washington. ${ }^{133}$ Kazakhstan has also contributed 27

${ }^{128}$ Olga Oliker, and David A. Shlapak, U.S. Interests in Central Asia: Policy Priorities and Military Roles (RAND Corporation: Santa Monica, Calif, 2005), p.48

${ }^{22} \mathrm{CICA}$ currently consists of 17 members (Afghanistan, Azerbaijan, China, Egypt, India, Israel, Iran, Kyrgyzstan, Mongolia, Pakistan, Palestine, Russia, Thailand, Turkey, Kazakhstan and Uzbekistan) and 9 observers (Australia, Indonesia, Japan, Republic of Korea, Lebanon, Malaysia, Ukraine, the USA and Vietnam).

${ }^{130}$ Bayles and Dunay, "The Shanghai Cooperation Organization as a regional security institution", p.14

${ }^{131}$ Kassymzhomart Tokaev, "Kazakhstan: strengthening security in Central Asia through democratic reforms and economic development", Address to the W.P. Carey Forum, Central Asia-Caucasus Institute, Washington D.C., July 5, 2006, <http://www.silkroadstudies.org/new/ inside/forum/> (accessed on May 09, 2007)

${ }^{132}$ Maksutov, The Shanghai Cooperation Organization: A Central Asian Perspective, $\mathrm{p} .7$

${ }^{133}$ D.R. Sands, "'Strategic' accord planned for Nazarbayev's U.S. visit", Washington Times, 8 July 2006 
personnel from its peacekeeping battalion (KAZBAT) as part of the international peacekeeping operation in Iraq with a mandate to carry out humanitarian activities. Given that Kazakhstan is the third largest men of the SCO and a country widely-respected for its stable policies, attempts to depict the SCO as an anti-Western-bloc are becoming frail.

Lastly, as Maksutov emphasizes, "the barely concealed internal contradictions within the SCO leave little room for the organization to evolve into a strong institutionalized alliance like NATO"..$^{34}$ Besides the earlier-discussed divergence of interests between Russia and China the Central Asian states are also beset by lack of natural empathy among each other as well as mutually-shared distrust towards larger powers in the region. ${ }^{135}$ Contradictions among Central Asian states reflect not only inter-state problems in the region but also disagreements among ruling elites on perspectives and issues facing the SCO. There are increasing signs of a certain sort of competition between Kazakhstan and Uzbekistan. One cannot totally discount the fact that Uzbekistan's relatively late joining of the SCO was conditioned by Tashkent's aspiration to minimize the risk of the SCO promoting interests and succumbing to domination of Kazakhstan in the region. In other words, by joining the SCO, Uzbekistan has had more opportunities to influence the shaping of events taking place within the SCO. On the other hand, since Kyrgyzstan and Tajikistan's respective relationships with Uzbekistan are not characterized by particular closeness, it could be assumed that through the SCO the latter two countries would strive to weaken Uzbekistan's leverage over them.

\subsection{The observer states}

As of today, India, Iran, Mongolia and Pakistan have been granted the status of observer states in the SCO. Mongolia became the first country to become an observer in 2004, while the other three states acquired the same status in 2005. ${ }^{136}$

${ }^{134}$ Maksutov, The Shanghai Cooperation Organization: A Central Asian Perspective, p.6

${ }^{135}$ More on factors leading to inter-state tensions in the Central Asian region see Internation Crisis Group (ICG), Central Asia: Border Disputes and Conflict Potential, ICG Asia Report No.33, (4 April 2002)

${ }^{136}$ Bayles and Dunay, "The Shanghai Cooperation Organization as a regional security institution", p.18
The status of observer was not foreseen in the SCO's original statutes and only following the 2004 summit was the regulation of observer status at the SCO adopted. The following rights are provided to observer states: a) to attend the open meetings of Council of Heads and/or the Council of Heads of Government (Prime Ministers) of SCO member states; b) to attend open meetings of the MFA Council and Conferences of Heads of Ministries and/or Departments of SCO member states; c) to participate in discussions over issues lying within the competence of the SCO institutions without the right to vote and with advance consent of the chairperson, to circulate through the SCO Secretary-General's statements, written in the working languages of the $\mathrm{SCO}$, on issues of their concern lying within the competence of the $\mathrm{SCO}$; d) to gain access to documents and decisions of the SCO institutions, if the relevant institutions of the SCO do not impose restrictions on their dissemination. ${ }^{137}$

As seen from the above regulation, whereas the heads of states and other high-ranking officials of observer states regularly participate in all higher-level meetings of the SCO such as summits of heads of state and meetings of heads of governments, representatives of observer states have no right to take part in lower-level meetings (expert and other levels) where the issues pertaining to security and economic cooperation are discussed in a greater detail.

As regards the observer states in the $\mathrm{SCO}$ as a group, Bayles and Dunay rightly note that "they form a disparate group, especially in terms of their degrees of democracy and of international acceptance and the nature of their group affiliations".138 The one motive for their association with the $\mathrm{SCO}$, as Bayles and Dunay further elaborate, "may reliably be attributed to all of them is an interest in the opening up of trade across Central Asia in general and joint approaches to (and possible Chinese investments in) trans-Asian energy deliveries and infrastructure links in particular"139

Since observer states, as mentioned above, have different motivations in participating in the $\mathrm{SCO}$, they have less at stake with regard to this

${ }^{137}$ See Regulations on Observer Status at Shanghai Cooperation Organization, Secsto. org, <http://www.sectsco.org/news_detail.asp?id=1485\&LanguagelD=2> (accessed on October 10, 2008)

${ }^{138}$ Bayles and Dunay, "The Shanghai Cooperation Organization as a regional security institution", p.18

Number 15-16, 2008- 2009 
organization and use it differently than the original members. India, which has been developing close relations with the US since recent times, places relatively low priority to the SCO constantly sending only low-key ministers to the SCO annual summits. Its main interest in the SCO is to use the organization as a means of balancing Pakistan. On the contrary, Pakistan has expressed its desire to join the SCO becoming the first country to apply for full membership. However, it would not be in the best interests of the SCO members to "import the India-Pakistan confrontation into the grouping as it has enough security problems and potential divisions already". 140

Furthermore, Iran has certain reasons to fully join the SCO and is more aggressive than India. Iran is isolated even in the Persian Gulf and faces pressure from the US, particularly on the issue of its nuclear program. For Iran, the SCO would provide a good avenue for maneuvering and balancing against the U.S. and Tehran is eager to join the SCO as a fullfledged member. Since Iran's joining the SCO as a member would make the organization look like an anti-US alliance or the very least, as a "rogue states' union", SCO member states would not be willing to offend the US by granting this status to Iran.

As far as Mongolia is concerned, it is the only country which faces no opposition from all SCO member states, if it expresses the interest in a full-fledged membership in the SCO. In particular, one of the leading Russian authorities on the SCO, Director of the Center of East Asia and SCO Studies at the Moscow State Institute of International Relations, Alexander Lukin argues that:

Admission of Mongolia into the SCO would have a great demonstration effect in terms of filling territorial "gap" in the SCO and stimulation of economic cooperation taking into consideration the high natural resource potentials of this country. A certain period has elapsed since this country has preferred economic orientation at the West Moreover, in the eyes of Washington, Mongolia serves as an example of a postcommunist democracy in Asia, for which it is natural to rely in its foreign policy exclusively on the US. Therefore, at least a partial reorientation of Ulan Bator towards SCO participant-states would be beneficial not only for Russia and China but for all participants. ${ }^{14 /}$

${ }^{140}$ Ibid., p.20

${ }^{141}$ Lukin "Rossiya i ShOS", pp.14-15
Moreover, even the SCO Secretary-General Bolat Nurgaliev has stated in his interview to a Mongolian newspaper Udriin Sonin that "if Mongolia joins the SCO as a member, this would not imply that it would restrict its partnership with America".142

However, at the moment Mongolia has no desire to become a member of the SCO preferring to keep its present observer status. Within the $\mathrm{SCO}$, Mongolia is primarily interested in the matters related to economic cooperation, particularly energy, infrastructure and transit traffic. As Japanese scholar Akihiro Iwashita concludes, Mongolia "hopes to develop its relations with the US and Japan as "third neighbour countries" beyond the border and it is not heavily invested in the "Shanghai spirit".143

To sum up, the specified interests of the SCO participants discussed here are in no way reminiscent to those of the Cold W ar era which makes it in turn impossible to turn this organization into a closed military bloc.

IV. Is the SCO a military alliance or not?

As demonstrated in the first part of this article, the majority of alliance theorists including Glenn Snyder, Roger Dingman, George Modelski, George Liska, Graham Evans and Jeffrey Newnham hold that "alliances" are primarily formal associations of states established against a third party. In particular, while noting that alliances are cooperative endeavors, Snyder asserts that the primary goal of alliances "is the prosecution of conflict with an outside party".144

If considered from this perspective, the SCO defies the conventional alliance theory. The SCO Charter, as well as the organization's other documents which define the aims and scope of activities of the SCO, explicitly emphasize that this organization is not directed against any states

${ }^{142}$ Yu. Delgermaa, "Bolat Nurgaliev: Mongol ShHAB-yn gishuuneer elsvel Ameriktai tunshilj bolohgui gesen yum baihgui" [Bolat Nurgaliev: If Mongolia joins the $\mathrm{SCO}$ as a member, this would not imply that it would restrict its partnership with America], Udriin Sonin, No.075 (2527), (April 30, 2007)

${ }^{143}$ Akihiro Iwashita, "The Shanghai Cooperation Organization and Japan: Moving Together to Reshape the Eurasian Community" Brookingsedu < <htp:/ www brookings. edu/articles/2008/0128_asia_iwashita.aspx? $=1>$ (accessed on August 05, 2008)

${ }^{144}$ Snyder, Alliance Politics, p.1 
or international organizations. ${ }^{145}$ Moreover, formation of a military alliance, which in the SCO'c case, is often claimed to be directed against the West or the US in particular, of the SCO but most importantly - the interests of its members, each of whom are interested in cooperation with the US and West in many areas, particularly in realization of their economic development tasks. In this connection, it would be perhaps useful to note that despite Russia's recent deterioration of relations with the West, China and other Central Asian members of the SCO, most notably Kazakhstan who maintain strong economic cooperation with the West, would not allow the SCO to turn into an anti-Western alliance.

As for other characteristics of an "alliance" including the conclusion of a defense pact that would operate in the event of war or preclusion for some or all members from joining other alliances, ${ }^{147}$ they do not fit in the case of the SCO. The SCO has no formal defense treaty that obliges its members to enter a war if any of its members is attacked. Instead, the Treaty on Long-term Good Neighborliness, Friendship and Cooperation signed by the $5 \mathrm{CO}$ member-states on August 16, 2007 in Bishkek stipulates in its article 6 that in case of emergence of a threat to security of any party to the treaty, it may hold consultations with other parties within the framework of the organization for an adequate reaction to such situation. ${ }^{148} \mathrm{Apart}$ from this multilateral treaty, the Russian-Chinese Treaty on Good Neighborliness, Friendship and Cooperation also contains an article on contacts and consultations in a similar situation. ${ }^{149}$

${ }^{145}$ See for example The Charter of Shanghai Cooperation Organization, June 07, 2002, Saint-Petersburg, and the Declaration on the Establishment of Shanghai Cooperation Organization, June 15, 2001, Shanghai

${ }^{116}$ Lukin and Mochulsky, "Shankhaiskaya organizatsiya sotrudnichestva: strukturnoye oformleniye i perspektivy razvitiya", p.16

${ }^{147}$ See Evans and Newnham, The Dictionary of International Relations, p.15

${ }_{148}$ Dogovor o dolgosrochnom dobrososedstve, druzhbe i sotrudnichestve gosudarstv-chlenov Shankhaiskoi organizatsii sotrudnichestva [The Treaty on Long-term Good Neighborliness, Friendship and Cooperation of States-Members of the Shanghai Cooperation Organization], Bishkek, 16 August 2007 [a Russian-language hardcopy of this document was obtained by author from the Ministry of Foreign Affairs of Mongolia]

${ }_{149}$ Stat'ya 9, Dogovor o dobrososedstve, druzhbe i sotrudnichestve mezhdu RF i KNR, Moskva, 16 iyulya 2001 g. [Article 9, The Treaty on Good Neighborliness, Friendship and Cooperation between the Russian Federation and the People's Republic of China, Moscow, July 16, 2001], Asiapacific.narod.ru, <http://asiapacific.narod.ru/countries/china/ treaty_about_peace.htm> (accessed on October 07, 2008)
However, it would be wrong to interpret the above clauses as a possibility for formation of an alliance. For instance, a similar clause can be found in the North Korea had formed an alliance. In the case of outbreak of a conflict between China and US over Taiwan, would Russia provide military support to China? Or if the US makes the Chinese strategic armaments irrelevant through introduction of TMD, would Russia be willing to take a risk of offering its nuclear "umbrella" to China? The answer to both questions is negative. ${ }^{150}$ China would prefer to maintain cordial relations with the US rather than to find itself under a Russian nuclear "umbrella", thereby allowing Russians to take the role of "big brother", which was the case in the beginning of the Cold War. ${ }^{151}$ Therefore, what is clear is the fact that no legal basis exists for turning the SCO into a military alliance.

Furthermore, if the SCO was a military alliance, the CSTO would not have approved the membership in the SCO of five of its seven members. On this point, one could argue that the US holds simultaneous memberships in a number of alliances such as NATO, ANZUS or bilateral alliance with Japan. However, all of the aforementioned US alliances have different geographical scopes. It could be observed that the geographical scope of both SCO and CSTO is the same post-Soviet space. If the SCO was a military alliance, there can be no doubt that its functions and activities would come into direct conflict with the Russian-dominated CSTO. And most importantly, Article 1 of the Collective Security Treaty (1992) which preceded the formation of CSTO in 2002 explicitly forbids the parties to join other military alliances. ${ }^{152}$

While comparing the $\mathrm{SCO}$ with contemporary military blocs such as NATO and CSTO, it is important to emphasize that the SCO lacks essential elements of a typical modern military alliance such as an integrated militarypolitical structure with permanent operational headquarters, a rapid reaction force, and continuous political deliberations which both NATO and CSTO have. ${ }^{153}$ Moreover, as Marcel de Haas convincingly argues:

${ }^{150}$ Akihiro Iwashita, "ShOS mozhet prevratit'sya vo vtoroye SNG" [SCO could turn into another CIS], October 10, 2007, Tazar.kg, <http://www.tazar.kg/news.php?i=513>1> (accessed on October 11, 2008)

${ }^{151} \mathrm{lbid}$.

${ }^{152}$ Dogovor o kollektivnoy bezopasnosti [Treaty on Collective Security], Tashkent, 15 May 1992, Dkb.gov.ru, <http://www.dkb.gov.ru/start/index.htm> (accessed on October 17,2008

${ }^{153}$ See de Haas, The Shanghai Cooperation Organisation's Momentum towards a Mature Security Alliance, pp.19-20 and p.30

Number 15-16, 2008- 2009 
An essential difference between the organizational development of the SCO and NATO is the fact that NATO is aimed primarily at external security risks teritory covered by its member states.

This lies in stark contrast to conventional alliance theory, which argues that alliances are first and foremost designed against external attacks. Although writers such as Richard Weitz have portrayed the abovementioned difference of the SCO from traditional military alliances as an inherent failure or weakness of the Shanghai process ${ }^{155}$, Bayles and Dunay underline that:

It would be impossible to imagine Russia guaranteeing China's entire territory against attack and vice versa, let alone Chinese and Russian forces - and potentially their nuclear weapons - being brought under a single command with joint forces. ${ }^{156}$

Having considered the differences of the SCO from traditional military alliances, it is equally important to mention their similarities. In particular grouping have used such activities as joint military exercises, staff training and weapons procurements which normally take place under the rubric of alliance relationship. For instance, besides Russian sophisticated arms and military technology sales to China, more than 500 Chinese students study in Russian military academies. ${ }^{157}$ Likewise, as Wilkins observes, Russian military advisers and scientists have flocked into China, recalling the heyday of the 1950's Sino-Soviet alliance. ${ }^{158}$ However, it should also be pointed out that SCO members' exchanges of defense equipment and technology are overwhelmingly bilateral, although there are some related joint capacity-building programs in the CIS and CSTO. ${ }^{159}$

${ }^{154}$ Ibid., p.30

${ }_{155}$ Richard Weitz, "Shanghai summit fails to yield NATO-style defence agreement" Jane's Intelligence Review, vol.18, no.8 (Aug.2006), p.42

${ }^{156}$ Bayles and Dunay, "The Shanghai Cooperation Organization as a regional security institution", p.22

${ }^{157}$ Stakelbeck, Jr., "Is the Shanghai Cooperation Organization a Military Confederacy?"

${ }^{158}$ Wilkins, Russia's' 'Strategic Partnerships:'Building A Framework For Analysis, p.22

${ }^{159}$ Bayles and Dunay, "The Shanghai Cooperation Organization as a regional security institution", p.21
As regards joint military exercises, these have included a Sino-Kyrgyz joint border security exercise in 2002; a multilateral exercise in eastern Kazakhstan and Chinese Xinjiang-Uighur Autonomous Region in 2003; a large Sino-Russian "Peace Mission 2005" exercise that was observed by other SCO member states; a multilateral "East Anti-Terror 2006" exercise hosted by Uzbekistan in 2006; and finally, "Peace Mission 2007" which was held from August 9-17, 2007 in Xinjiang, PRC as well as in Russia's Chelyabinsk oblast' (province) with participation of all SCO members. ${ }^{160}$

Since the key security objective of the SCO lies in combating threats posed by "terrorism, separatism and extremism", the scenarios of the exercises were related to the above themes. However, these exercises, especially, Peace Mission 2005 and Peace Mission 2007 were seen by some Western analysts ${ }^{161}$ as clear proof that Russia and China aim to create a military bloc to counterbalance NATO and diminish the US presence in Central Asia. Indeed, deployment of Tu-22 and Tu-95 strategic bombers, missile destroyers, submarines and AWACS during the Peace Mission 2005 exercise led many observers to question the alleged "antiterrorist" or "peace support mission element".162 What is more, the fact that the exercise was held almost immediately after the SCO's Astana Summit which demanded the US set a timeline for withdrawal of its military bases from the Central Asian region indicates that "the signals it conveyed about Chinese-Russian capacity and resolve were not aimed exclusively at potential non-state adversaries". 163

As for the Peace Mission 2007, unlike Peace Mission 2005 it did not involve the use of heavy military equipment. ${ }^{164}$ Roger McDermott considers that this exercise was unique since it included all of the SCO member

${ }^{160} \mathrm{For}$ more detailed analysis of these exercises see Roger N. McDermott, The Rising Dragon: SCO Peace Mission 2007, The Jamestown Foundation, (October 2007)

${ }^{161}$ See for example Cohen and Tkacik, Jr., "Sino-Russian Military Maneuvers: A Threat to U.S. Interests in Eurasia"; and Stakelbeck, Jr., "Is the Shanghai Cooperation Organization a Military Confederacy?"

${ }^{162}$ McDermott, The Rising Dragon: SCO Peace Mission 2007, p.6

${ }^{163}$ Bayles and Dunay, "The Shanghai Cooperation Organization as a regional security institution", p.23

${ }^{164}$ McDermott, The Rising Dragon: SCO Peace Mission 2007, p.11 
states. ${ }^{165}$ Moreover, the Peace Mission 2007 was significant in that "it was the first time that the PLA had ever sent complete organizational units to take part in a joint anti-terrorism military exercise outside China"166 As the Chinese conducted an intense media campaign to showcase to the world the "most open exercise ever", this served Beijing's goal to establish the positive international image of a modernized Chinese military. ${ }^{167}$ But the overwhelming significance of the SCO exercise for China remains in its concern with the problems of separatism and terrorism in Xinjiang, making it imperative to closely collaborate with its SCO counterparts in this respect.

In Moscow's case, as McDermott rightly observes, its agenda differs from Beijing in less than subtle ways. ${ }^{168}$ He further refers to Vitaliy Shlykov, a member of the Foreign and Defense Policy Council in Moscow, who indicated that Peace Mission 2007 should be understood in the wider strategic context of difficulties that emerged in Russia's relationship with the West. ${ }^{169}$ In particular, the US unilateral plans to deploy BMD components in Poland and the Czech Republic are seen by Moscow as a direct challenge to its standing as a great power. As Eugene Rumer observes, the deployments represent a problem for Russian military planners largely due to a possibility of US interceptors interdicting Russian missiles during the early boost phase, and also because of the challenge it could present to Russia's strategic parity with the US. ${ }^{170}$ In addition, given that the Baltic countries are already NATO members, while pro-Western governments in Georgia and Ukraine that came into power as a result of "color revolutions" in 2003 and 2004, make no secret of their plans to follow in footsteps of the former, Russia is increasingly seeing itself as being encircled. Therefore, Shlykov argues that:

The claims of the United States and NATO to primacy in the world should have some counterweights. There is no doubt that today Russia needs allies, especially in the region as complex as

\section{${ }^{165}$ bid., p.13 \\ ${ }^{166} \mathrm{lbid}$. \\ ${ }^{167}$ lbid., p. 19 \\ ${ }^{168} \mathrm{lbid}$., p.22 \\ ${ }^{169} \mathrm{Ibid}$.}

${ }^{170}$ Eugene B. Rumer, "Russian Foreign Policy Beyond Putin”, Adelphi Papers, Vol.47, No. 390, (2007), p.26
Asia... Not a single state can get along today without allies. We are responding to America's aspirations to world hegemony by various means, 0 (he $\mathrm{SCO}$ military-political vector is just one. ${ }^{171}$

In this sense, as mentioned earlier, Russia's active involvement with China within the framework of the SCO can be regarded as an attempt to seek an alliance against a threat which is consistent with Stephen Walt's "balance of threat theory".172 As Walt suggests, "states ally to balance against threats rather against power alone".173 Hence, taking into account that in the longer term, both Russia and China are interested in maintaining positive relations with the US, balancing against threats posed by US unilateral actions sounds more plausible than the Cold War-style "balance of power" based on a zero-sum game. Russia values China's cooperation in voicing opposition to American hegemony, but it knows that this would not extend to endangering China's economic ties with the US.

In addition, the earlier-mentioned divergent political and economic interests as well as internal contradictions between SCO member states make it clear that at the moment it is premature to conclude that this organization is turning into a full-grown security organization, let alone a military alliance. In this context, the avoidance of explicit support of SCO members at the grouping's latest summit held at Dushanbe in August 2008, from providing unequivocal support to Russia's recent recognition of the independence of South Ossetia and Abkhazia from Georgia, is an important reminder for the fact that it is still too early to consider this organization as a unified bloc. ${ }^{174}$ Given that the principle of territorial integrity is a

${ }_{171}$ Vitaliy Shlykov quoted in McDermott, The Rising Dragon: SCO Peace Mission 2007, p.22

${ }^{172}$ See Walt, Origins of Alliances, pp.21-26

${ }^{173} 3$ bid., p. 5

${ }^{174}$ See for example "Russia: The Kremlin Tries to put on brave face following diplomatic slap over Georgia", Eurasianet.org, August 29, 2008, <http://www.eurasianet. org/departments/insight/articles/eav082808b_pr.shtml> (accessed on August 30, 2008); Dilip Niro, "Russia's one step too far", guardian.co.uk, <http://www.guardian.co.uk/ commentisfree/2008/aug/29/russia.china> (accessed on August 30, 2008); David L. Stern, "Security Group Refuses to Back Russia's Actions", The New York Times, August 29, 2008, <http://www.nytimes.com/2008/08/29/world/europe/29russia.html> (accessed on August 29, 2008) 
"sacred cow" for China as well as for Central Asian states which have their own ethnic minorities with the potential for conflict, such stance of SCO member states should serve as no surprise.

In light of all the above-mentioned conceptual and empirical factors, it could be observed that the cooperation among SCO members including its military-political component does not imply that its members had formed an "alliance" but at best can be described as one form of an "alignment". As Snyder demonstrates, it is useful to stipulate somewhat different meanings between the two terms. ${ }^{175}$ Thus, as discussed earlier, whereas alliance is defined by Snyder "as a formal association of states for use or non-use of military force against states outside their own membership", "alignment" refers to "expectations of states about whether they will be supported or opposed by other states in future interactions."176 According to Snyder "formal alliances are simply one of the behavioral means to create or strengthen alignments".177 Moreover, he provides several reasons for possible emergence of "alignment", from which the following one may be more or less relevant to the SCO - "expectations of support may be created by various behavioral means, such as joint military planning or diplomatic statements and agreements of various kinds, up to and including formal alliances.".178

Since the "pattern of alignment" throughout the international system is always vague and constantly changes with changing patterns of power, interests and issue priorities, ${ }^{179}$ it seems that no definitive answer can be given to the question of whether cooperation among the SCO states can be regarded as a typical form of "alignment" in accordance with alliance theory. As mentioned in the first chapter of this thesis, according to the Chinese and Russians, the SCO represents a completely new model of state-to state relations which transcends the Cold War mentality and therefore, it is characterized by partnership but not alliance. Hence, the cooperation among SCO participants might be considered as an alternative alignment system which cannot be fully explained by traditional realist alliance theory.

${ }^{175}$ See Snyder, Alliance Politics, pp.6-16
${ }^{176} \mathrm{lbid}$., p.6
${ }^{177} \mathrm{lbid}$., p. 8
${ }^{178} \mathrm{lbid}$., p.7
${ }^{179} \mathrm{lbid}$.

Conclusion

Covering one of the largest geographical areas of any regional organization and encompassing a population of 1.5 billion people, which is around a quarter of the world's population, there is no doubt that the Shanghai Cooperation Organization is becoming an influential force in international arena. As this organization has been labeled by some commentators in the West as the "NATO of the East" or a new Warsaw Pact ${ }^{180}$, this article has attempted to determine whether this organization indeed represents an example of a military alliance.

In order to find an answer to this question, it has examined at first the history of the SCO starting from birth of the Shanghai Five in 1996 and its subsequent evolution, and second, it discussed the specific interests of participants in the SCO. With this history in mind, the article then applied alliance theory to help answer this question, which might be considered as a modest contribution to a more objective analysis of the SCO. The findings of the research are as follows:

First, despite the SCO's rhetoric, some of its actions contain elements of counterbalancing against the West, particularly the US, witnessed in its strongly-stated stance demanding the US to withdraw from the SCO sphere. Moreover, the fact that its supposedly "counter-terrorist" exercises, most notably Peace Mission 2005 involved forces and activities more relevant to a high-intensity warfare against another alliance, substantiates the above claim.

Nevertheless, this organization is not and never could be a fully-fledged military alliance. The divergent strategic priorities of its two predominant members - China and Russia, as well as internal contradictions among its Central Asian members indicate that it is unlikely for the SCO to develop into a powerful united bloc that could present a challenge, let alone a threat to Western interests. Moreover, as emphasized in fourth part, not only will it contradict the principles of this organization, stated in all its official documents, but it will also run against long-term strategic interests of its members. As the Chinese scholar

${ }^{180}$ Fred Weier, "Russia, China looking to form 'NATO of the East?", The Christian Science Monitor, October 26, 2005; Frederick W. Stakelbeck Jr., "A New Bloc Emerges?", Americanthinker.com, August 5, 2005, <http://www.americanthinker.com/articles. php?article_id=4703> (accessed on July 30,2007 ) 
Yu Bin notes "this is not a mere rhetoric to calm down Washington, but reflects a strategic fact of life".18

Second, from a conceptual perspective, the application of alliance theory has demonstrated that the SCO falls short of a typical military alliance. Moreover, I argue that traditional alliance theory has a limited application to explaining the phenomenon of $\mathrm{SCO}$. The closest resemblance it has with what is discussed in conventional theory is with the "pattern of alignment". Therefore, in words of Wilkins, "those who talk of "NATO of the East" or new Eastern bloc miss the point."182 In case of the SCO, a formal alliance along the lines of Cold War period is neither intended nor required. The $\mathrm{SCO}$ is a less strict instrument. As it is primarily based on Russo-Chinese strategic partnership, the point which was emphasized above, it represents a new type of looser, more informal, and flexible alignment systems that are emerging in the 21 st century. As Lo asserts "the strategic partnership is a dynamic rather than a static phenomenon, " par er "truth" and principles, but flexible in its response to events and emerging international trends".18

This, in my view, most eloquently captures the debate on whether the $\mathrm{CO}$ can be considered as a military alliance or not. Therefore, despite the fact that the SCO is not a military alliance from theoretical and empirical perspectives, it nevertheless contains potential of evolving into a more mature security organization which does not necessarily have to conform to traditional alliance theories.

\section{Bibliography}

Bayles, Alyson J.K. and Pal Dunay. "The Shanghai Cooperation Organization as a regional security institution", The Shanghai Cooperation Organization, SIPRI Policy Paper No.17, (Stockholm: Stockholm International Peace Research Institute, May 2007).

Brookes, Peter. "Club For Dictators: An ugly agenda for Asia", The Heritage Foundation, June 12, 2006, Heritage.org, <http://www.heritage.org/Press/ Commentary/ed061206b.cfm> (accessed on April 09, 2007).

${ }^{181}$ Yu Bin, "Central Asia Between Competition and Cooperation", Foreign Policy in Focus, (December 2006), <http://www.ciaonet.org/cgi-bin/dkv/ciao/querystring.pl?q=0\&ht=0\&qp=\& col=ciao\&qc=ciao\&qt=china+and+central+asia> (accessed on May 6,2008 )

${ }^{182}$ Wilkins, Russia's'Strategic Partnerships:' Building A Framework For Analysis, p.33

${ }^{183}$ Lo, "The Long Sunset of Strategic Partnership: Russia's Evolving China Policy", p.300
The Charter of Shanghai Cooperation Organization, June 07, 2002, Saint-Petersburg, Sectsco.org, http://www.sectsco.org/news detail. asp?id=96\&LanguagelD=2 (accessed on August 20, 2008)

Cohen, Ariel and Tkacik, Jr., John J. "Sino-Russian Military Maneuvers: A Threat to U.S. Interests in Eurasia", The Heritage Foundation, Backgrounder 1883, September 30, 2005, Heritage.org, <http://www.heritage.org/research/ russiaandeurasia/bg1883.cfm $>$ (accessed on August 21, 2008).

"CNPC secures PetroKazakhstan bid", BBC News, 26 October 2005, $<$ http://news.bbc. co.uk/2/3723249.stm> (accessed on October 07, 2008).

The Declaration on the Establishment of Shanghai Cooperation Organization, June 15, 2001, Shanghai, Sectsco.org, <http://www.sectsco.org/html/00088.html> (accessed on March 25, 2007).

The Declaration of Heads of Member States of the Shanghai Cooperation Organization, Astana, 5 July 2005, Sectsco.org, <http://www.sectsco.org/ html/00500.html $>$ (accessed on March 21, 2007).

Delgermaa, Yu. "Bolat Nurgaliev: Mongol ShHAB-yn gishuuneer elsvel Ameriktai tunshilj bolohgui gesen yum baihgui" [Bolat Nurgaliev: If Mongolia joins the $\mathrm{SCO}$ as a member, this would not imply that it would restrict its partnership with Americal, Udriin Sonin, No.075 (2527), (April 30, 2007).

Dogovor o dolgosrochnom dobrososedstve, druzhbe i sotrudnichestve gosudarstv-chlenov Shankhaiskoi organizatsii sotrudnichestva [The Treaty on Long-term Good Neighborliness, Friendship and Cooperation of States-Members of the Shanghai Cooperation Organization], Bishkek, 16 August 2007 [a Russianlanguage hardcopy of this document was obtained by author from the Ministry of Foreign Affairs of Mongolia].

Dogovor o dobrososedstve, druzhbe i sotrudnichestve mezhdu RF i KNR, Moskva, 16 iyulya 2001 g. [The Treaty on Good Neighborliness, Friendship and Cooperation between the Russian Federation and the People's Republic of China, Moscow, July 16, 2001], Asiapacific.narod.ru, <http://asiapacific.narod.ru/ countries/china/treaty_about_peace.htm $>$ (accessed on October 07, 2008) 
Dogovor o kollektivnoy bezopasnosti [Treaty on Collective Security], Tashkent, 15 May 1992, Dkb.gov.ru, <http://www.dkb.gov.ru/start/index.htm> (accessed on October 17, 2008)

Dushanbe Declaration by the Heads of State of the Republic of Kazakhstan, of the People's Republic of China, of the Kyrgyz Republic, of the Russian Federation, and of the Republic of Tajikistan, Shanghai Five, June 6, 2000, Mid. ru, <http://www.In.mid.ru/Bl.nsf/0/A69BB7197B47EC174325699C003B5F9D ?OpenDocument> (accessed on March 20, 2007)

Dingman, Roger V. "Theories of, and Approaches to, Alliance Politics", in Paul Gordon Lauren, ed., Diplomacy: New Approaches in History, Theory and Policy, (London: Collier Macmillan Publishers, 1979), pp.245-266.

Evans, Graham and Newnham, Jeffrey. The Dictionary of International Relations, (Penguin Books, 1998).

Goldsmith, Benjamin. "Here There Be Dragons: The Shanghai Cooperation Organization", The Center for Defense Information, September 2005, Ciaonet. org, <http://www.ciaonet.org/wps/cdi014/> (accessed on March 20, 2007).

de Haas, Marcel. The Shanghai Cooperation Organisation's Momentum towards a Mature Security Alliance, (The Hague: Netherlands Institute of International Relations, 2007), <http://www.clingendael.nl/publications/2008/20080100-cscphaas-art-sm.pdf $>$ (accessed on October 17, 2008).

"History of development of Shanghai Cooperation Organisation", Sectsco. org, <http://www.sectsco.org/html/00035.html> (accessed on March 20, 2007).

International Crisis Group (ICG), Central Asia: Border Disputes and Conflict Potential, ICG Asia Report No.33, (4 April 2002).

Iwashita, Akihiro. "The Shanghai Cooperation Organization and Japan: Moving Together to Reshape the Eurasian Community", Brookings.edu, <http:// www.brookings.edu/articles/2008/0128_asia_iwashita.aspx?=1> (accessed on August 05, 2008).
Iwashita, Akihiro "ShOS mozhet prevratit'sya vo vtoroye SNG" [SCO could turn into another CIS], Tazar.kg, <http://www.tazar.kg/news.php?i=513>1> (accessed on October 11, 2008)

Khaphizova, K. "Separatizm v Sin'dzyan-Uigurskom avtonomnom raione Kitaya: Dinamika i potentsial vliyaniya na situatsiyu v Tsentral'noi Azii" [Separatism in Xinjiang-Uighur Autonomous Region of China: Dynamics and Potentials of its Impact on the Situation in Central Asia], Tsentral'naya Aziya i Kavkaz, No.1, (2003), <http://www.ca-c.org/journal/rus-01-2003/01/khaprimru. shtml> (accessed on 09 August 2008).

Lo, Bobo. "The Long Sunset of Strategic Partnership: Russia's Evolving China Policy", International Affairs, Vol.80, No.2 (2004), pp.295-309.

Lukin, Alexander and Sanakoev, Sergei. "Rossiiskii podhod k Kitayu na rubezhe vekov: problemy i resheniya" [Russia's Approach towards China at the threshold of centuries: problems and solutions], Analyticheskiye Zapiski, no. 5(7) (Apr.2005).

Lukin, Alexander and Mochulsky, Alexei. "Shankhaiskaya organizatsiya sotrudnichestva: strukturnoye oformleniye i perspektivy razvitiya" [Shanghai Cooperation Organization: structural formation and perspectives of development], Analyticheskiye Zapiski, no. 2(4) (Feb.2005).

Lukin, Alexander. "Shankhaiskaya organizatsiya sotrudnichestva: chto dal'she?" [Shanghai Cooperation Organization: what lies ahead?], Rossiya v global'noi politike, No.3, (May-June 2007), <http://www.globalaffairs.ru/ numbers/26/7700.html> (accessed on April 03, 2007).

Lukin, Alexander. "Rossiya i ShOS" [Russia and SCO], Analyticheskiye Zapiski, no.6 (26) (Jul.2007).

Maksutov, Ruslan. The Shanghai Cooperation Organization: A Central Asian Perspective, SIPRI Project Paper, (Stockholm: Stockholm International Peace Research Institute, August 2006), <http://www.sipri.org/contents.worldsec/ eurosec.html> (accessed on May 07, 2007). 
McDermott, Roger N. The Rising Dragon: SCO Peace Mission 2007, The Jamestown Foundation, (October 2007).

Modelski, George. "Review: The Study of Alliances", The Journal of Conflict Resolution, Vol.7, No.4 (December 1963), pp.769-776. 2001).

NATO Handbook 2001, (Brussels: NATO Office of Information and Press,

Nourzhanov, Kirill. "Caspian oil: geopolitical dreams and real issues", Australian Journal of International Affairs, Vol.60, No.1, (March 2006), pp.59-66.

Niro, Dilip. "Russia's one step too far", guardian.co.uk, <http://www. guardian.co.uk/commentisfree/2008/aug/29/russia.china> (accessed on August $30,2008)$

Nye, Jr., Joseph S. Understanding International Conflicts, (New York: Longman, Sixth Edition, 2007).

Olcott, Martha Brill. The Shanghai Cooperation Organization: Changing the "Playing Field" in Central Asia, Testimony before the Helsinki Commission, (September 26, 2006),

$<\mathrm{http}: / /$ www.carnegieendowment.org/files/MBO0906.pdf> (accessed on March 20, 2007)

Oliker, Olga and Shlapak, David A. U.S. Interests in Central Asia: Policy Priorities and Military Roles (RAND Corporation: Santa Monica, Calif., 2005)

Pan, Guang. "A Chinese Perspective on the Shanghai Cooperation Organization", The Shanghai Cooperation Organization, SIPRI Policy Paper No.17, (Stockholm: Stockholm International Peace Research Institute, May 2007), pp.45-58.

Pocha, Jehangir S. "Summit forges military ties in Central Asia. Six nations also consider forming an 'energy club"', The Boston Globe, June 18, 2006.
Putin, Vladimir. "SCO: a new model of successful international cooperation", Moscow, June 14, 2006, Kremlin.ru, <http://www.kremlin.ru/eng/sdocs/speeches. shtml> (accessed on April 04, 2007).

Regulations on Observer Status at Shanghai Cooperation Organization, Secsto.org, <http://www.sectsco.org/news_detail.asp?id=1485\&LanguagelD=2> (accessed on October 10, 2008).

Rumer, Eugene B. "Russian Foreign Policy Beyond Putin", Adelphi Papers, Vol.47, No. 390, (2007).

"Russia: The Kremlin Tries to put on brave face following diplomatic slap over Georgia", Eurasianet.org, August 29, 2008, <http://www.eurasianet.org/ departments/insight/articles/eav082808b_pr.shtml> (accessed on August 30, 2008).

Sands, D.R. "'Strategic' accord planned for Nazarbayev's U.S. visit", Washington Times, 8 July 2006.

Shanghai Convention on Combating Terrorism, Separatism and Extremism, Shanghai, June 15, 2001, Sectsco.org, <http://www.sectsco.org/html/0093> (accessed on March 25, 2007)

Shirk, Susan L. "China's Multilateral Diplomacy in the Asia-Pacific", Before the U.S.-China Economic and Security Review Commission "China as an Emerging Regional and Technology Power: Implications for U.S. Economic and Security Interests", February 12-13, 2004, Uscc.gov.,

http://www.uscc.gov/hearings/2004hearings/written testimonies/04_02_12wrts/shirk.htm (accessed on August 14, 2008)

Shirk, Susan L. China, Fragile Superpower, (Oxford University Press, 2007).

"ShOS suzhdeno stat' voyennym al'yansom" [SCO is destined to become a military alliance], Rambler.ru, May 15, 2008, <http://www.rambler.ru/news/ politics/0/562184254.html> (accessed on August 25, 2008).

Snyder, Glenn H. Alliance Politics, (Ithaca and London: Cornell University Press, 1997). 
Schroeder, Paul W. "Alliances 1815-1945: Weapons of Power and Tools of Management", in Klaus Knorr, ed., Historical Dimensions of National Security, (Lawrence: University Press of Kansas, 1976), pp.227-262.

Stakelbeck Jr., Frederick W. "A New Bloc Emerges?", Americanthinker.com, August 5, 2005, <http://www.americanthinker.com/articles.php?article_id=4703> (accessed on July 30, 2007).

Stakelbeck, Jr., Frederick W. "Is the Shanghai Cooperation Organization a Military Confederacy?", Globalpolitician.com, $<$ http://www.globalpolitician. com/21244-russia-china> (accessed on October 17, 2008).

Stern, David L. "Security Group Refuses to Back Russia's Actions", The New York Times, August 29, 2008, <http://www.nytimes.com/2008/08/29/world/ europe/29russia.html> (accessed on August 29, 2008).

Tokaev, Kassymzhomart. "Kazakhstan: strengthening security in Central Asia through democratic reforms and economic development", Address to the W.P. Carey Forum, Central Asia-Caucasus Institute, Washington D.C., July 5, 2006, $<$ http://www.silkroadstudies.org/new/inside/forum/> (accessed on May 09, 2007)

Troitskiy, Mikhail. "A Russian Perspective on the Shanghai Cooperation Organization", The Shanghai Cooperation Organization, SIPRI Policy Paper No.17, (Stockholm: Stockholm International Peace Research Institute, May 2007), pp.30-44.

Turner, Jefferson E. "What is Driving India's and Pakistan's Interest in Joining the Shanghai Cooperation Organization?", Strategic Insights, Volume IV, Issue 8 (August 2005) [no page number].

Walt, Stephen M. The Origins of Alliances, (Ithaca and London: Cornell University Press, 1987).

Watts, Jonathan. "China Hosts Summit to Rival US", The Guardian, 15 June 2006
Weier, Fred. "Russia, China looking to form 'NATO of the East?", The Christian Science Monitor, October 26, 2005.

Weitz, Richard. "Shanghai summit fails to yield NATO-style defence agreement", Jane's Intelligence Review, vol.18, no.8 (Aug.2006).

Wilkins, Thomas S. Russia's 'Strategic Partnerships:' Building A Framework For Analysis, (San Francisco: University of San Francisco, Center for the Pacific Rim, November 06, 2007), <http://www.allacademic.com//meta/p_mla_apa research_citation/2/5/4/0/3/pages254031/p254031-1.php $>$ (accessed on October $07,2008)$.

Xinhua, "China's CITIC Group acquires Kazakhstan oil assets for $1.91 \mathrm{bln}$ US dollars", People's Daily (English edition), 1 January 2007.

Yang, Jiechi. "Eternal driving force of Shanghai Spirit", Renmin Ribao, June 16, 2008 [a Mongolian translation of this article was obtained by author from the Ministry of Foreign Affairs of Mongolia].

Yu, Bin. "Central Asia Between Competition and Cooperation", Foreign Policy in Focus, (December 2006), <http://www.ciaonet.org/cgi-bin/dkv/ciao/

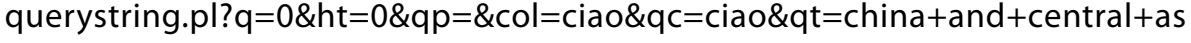
ia> (accessed on May 6, 2008)

Zhao, Huasheng. Kitai, Tsentral'naya Aziya i Shankhaiskaya Organizatsiya Sotrudnichestva [China, Central Asia and the Shanghai Cooperation Organization], Carnegie Moscow Center Working Paper 5/2005, (Moscow: Carnegie Moscow Center, 2005), <http://www.carnegie.ru/en/pubs/workpapers/73064.htm> (accessed on August 08, 2008).

Zhao, Huasheng. "Central Asia in China's Diplomacy", in Eugene Rumer, Dmitri Trenin and Huasheng Zhao, Central Asia, Views from Washington, Moscow and Beijing (Armonk, New York, London, England: M.E. Sharpe, 2007), pp.137-213 